\title{
System of Volcanic activity
}

\author{
P. HÉDEIVÁRI (*)
}

Ricevulo il 14 Magrin 1971

Sumarr. - A new system (elassification) of volcanic activity is presented for the fast retermination of certain important rlata on the basis of the observed characteristics of phenomena in the ease of a griven eruption. The main purpose of the present paper boside this is to show the extremely wisle variety of the mechanism of voleanic aclivity.

The system is based on the gras-content of fresh lava on one hand and on the viscosity of it on the other. The classification is basically similar to the system publishou by Profossor R. W. van Bemmelen. The new system - howover - differs from the original one of van Bemuelen since the present anthor took into account some subtypes and transitions annong the classical types. On the olher hand the author introduced some further types into his new sysiem, for instant the "Alphonsus" type, the "Rift. valley" lype, eic. Altogether 28 more or less different types are distin. guishable. The sum of the subtypes is not included.

Riassunto. - Vieno esposto un nuovo sistema (elassificaziono) di attivití vuleanica per l'accurata determinazione di corli importanti dati, tenendo conto delle caratteristiche dei fenomeni osservati nel caso di alcume eruzioni. Oltre a ciò, lo scopo principale della presente nota è quello di far vedere quanito estremamento vasta sia la varietà del meccanismo dell'attività vuleunica.

Il sistema si basa sia sul contennto di gras tella lava fresca sia sulla sua viscosità.

Ja classificazione of fondamentalmente simile al sistema studiato e pubblicato dal l'rof. R. W. van Bemmolen. Il nuovo sistema, tuttavia, differisce da quello originale di van Temmelen perché nel presente lavoro I'autore prende in considerazione - fra i tipi clissici - alcuni sotbotipi e uran-

(*) Dr, rer. nat., F.R.A.S., Vico-Presislent of International Association of Planetology (IUGS-UNESCO); President of International Innar So. ciety: Budapest (Untgheria). 
sizioni. D'altra parte l'autoro introduce nel suo nuovo sistema, nlteriori tipi, quali l'u Alphonsus ", il "Rift-valley "ete. Complessivanente ì possibile distinguere cirea 28 tipi diversi, ai quali va aggiunto l'insieme dei sottotipi già citati.

\section{INTRODLOTION.}

In the voleanology there is a classical system of the volcanic activity, the short history and the base of which were described almost in all of the voleanological textbooks. We may refer liere only to four of them: Bullard $\left({ }^{3}\right)$, Cotton $\left({ }^{4}\right)$, Rittmamn (17) and Tazieff (19).

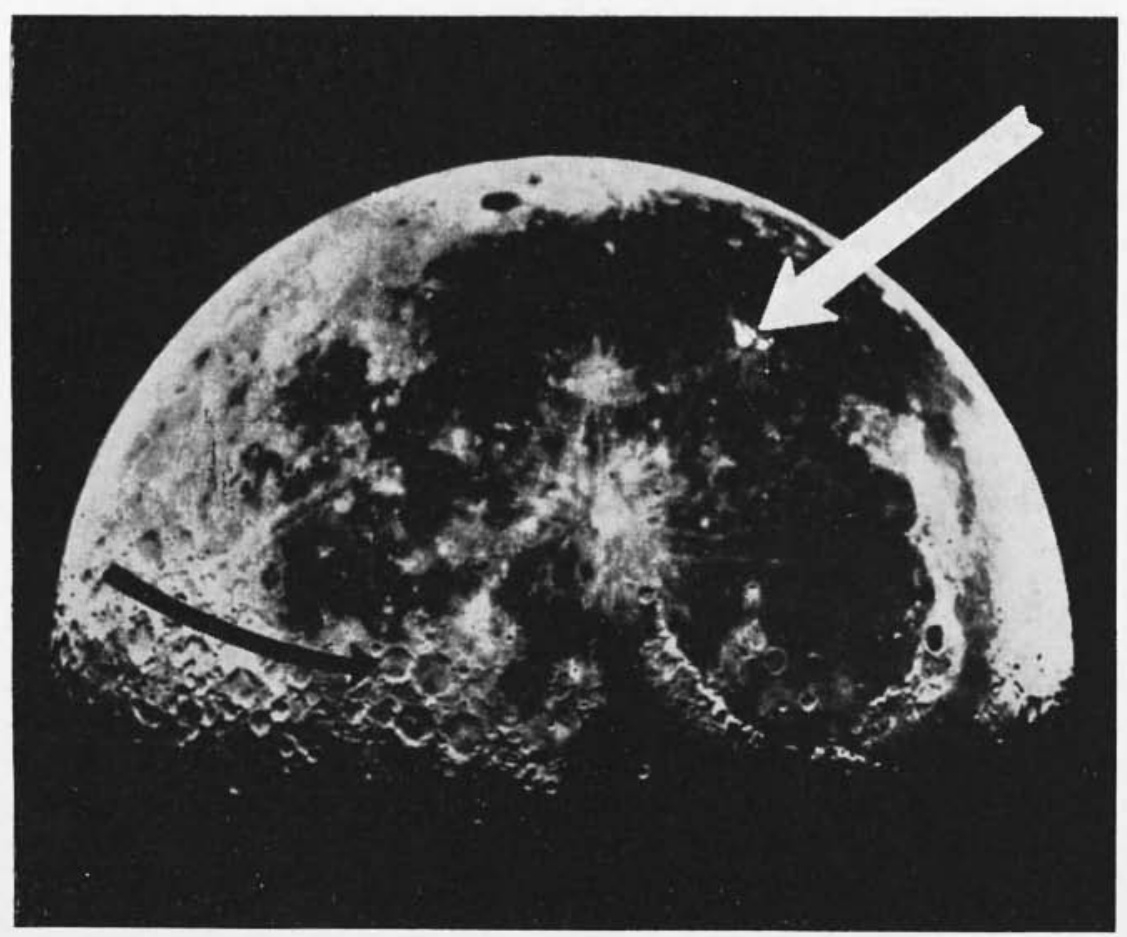

Plonto I - The site of the two most ative areas of the lunar surface. Black arrow: Alphonsus, white arrow: Aristarehus.

In two briliant papers, van Bemmelen (1,2) has presented a classification on entircly physical base, namely on the basis of viscosity and gas-content of fresh lava. This excellent system consists of all the 
most important fundamental types (classes) of eruptions, but without the possible transitional- and subtypes.

In the present paper the author is trying to enlarge the system of van Bemmelen and thus to include the important transitional- and subtypes into the new classification. It is possible now, owing to the valuable new results of the recent theoretical and field investigations, carried out by voleanologists over different parts of the world.

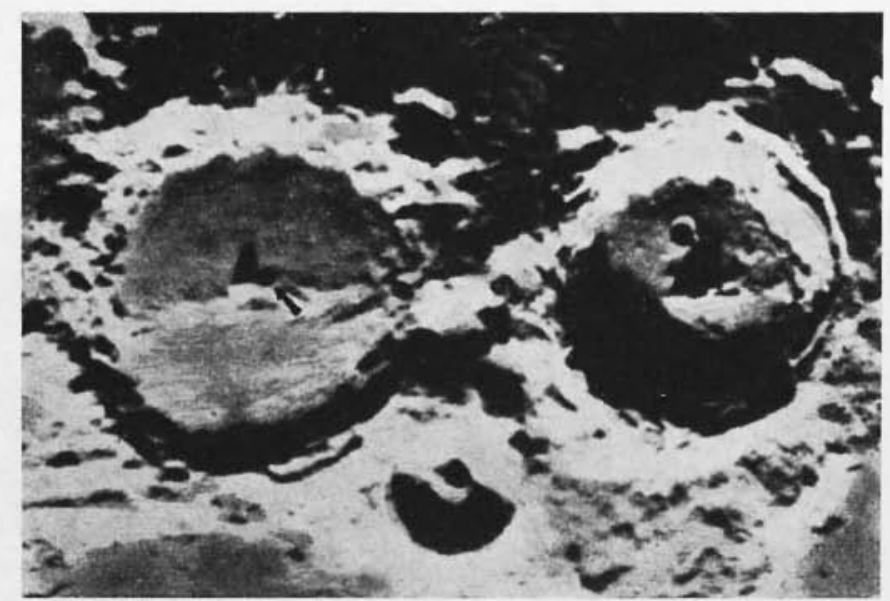

Plioto 2 - The Alphonsise. The small arrow shows the site of the new reddish spot, observed by Wilkins.

Needless to say that this new system is more complicated than that of the original one of van Bemmelen. Its main purpose is twofold. Practically: in spite of the difficulties arising by the complicated form of the new system, the author hopes very much that this classification may be useful for the experts, as a work-help table for the fast, approximate determination of many data, taking into account the main characteristics of the observed factors in the case of a given eruption. However, to use the system in the practice really is not too easy, since the system is somewhat too elaborated and in many cases it goes into the thiniest details as well. The question, whether the respective system really is useful in the practice or not, will be answered in the future by those experts who will try to apply it. It is possible that some alterations, especially simplifications will be required.

Concerning this point it must be emphasized that there are neither "absolute cathegories" nor "pure types". Hvery voleano is a unique 
"individuality" and the character of eruptions may change between two successive oycles of activity of the same volcano, the more, it may change during one cycle of eruptions. As Professor van Bemmelen had the kindness to call the author's attention: "On the top of every volcanic cycle the activity is unique in its own way, apłart from some general characteristic trends" (personal communication). These general Alaracteristics are given in vıı Bemmelen's original system. J)uring one cycle of activity, or during more cycles which follow each-other in the case of the same volcano, several types of activity might be shown successively. Accordingly, the theoretical purpose of the present paper is to show the great variousness, the munifollness of the external volcanic phenomena.

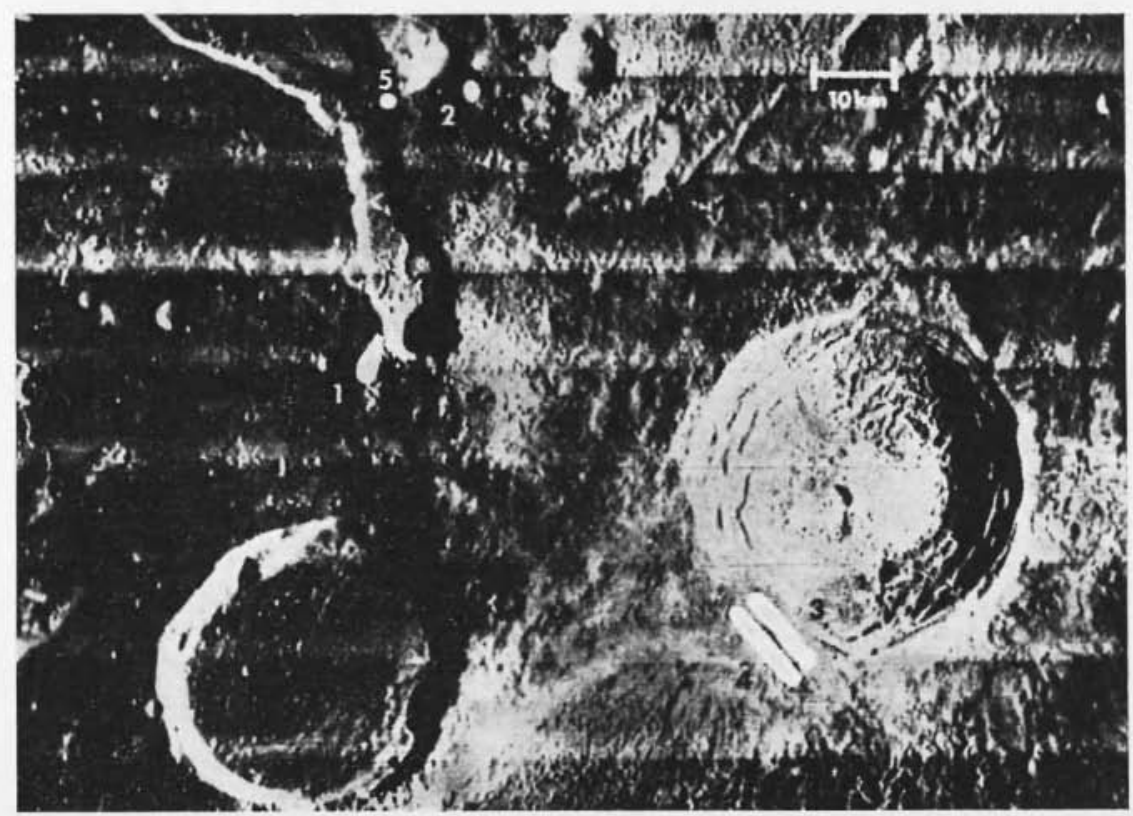

Photo 3 - The site of five reddish patch noar to Aristarchus.

To make distinctions among the different kinds of volcanic activity often is rather difficult, especially in the case when the place of a volcano inside the system is very near to the place of an other one. They have many common features, while other characteristics of them may be difierent. It is not possible to set sharply a limit between the respective types. For example: according to Professor van Bemmelen (also personal communication) the most important aspects, 
determining the classification in the case of types 25 (Vesuv-II) and 26 (Santorin) were the high explosivity, self-induction and the terminal Perret-phake; wlile the other aspects, which represent rather fliflerences than sinilarities between them, harl only a secondary role. Such necondary factors were as follows:

The Vesur in $79, A .13 .,-$ as well as the Merapi in 1(606, A. D., were destroyed by gravity slides, producing the somma walls, but not caldera's, while in the case of the so called Minoan erujtion of Santorin a mighty calciera originated by the eollapse of the roof of the magma reservoir. The eruption of Vesur in $1906 \mathrm{~A}$. D. destroyed only the top part of the voleanic cone.

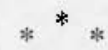

To use the elaborated new system - in spite of its rather complicated form - the knowledge of only two data, which are at the same time the base of van Bemmelen's system as well, is indispensable. However these two data are basic and of capital importance. The respective data are as follows:

a) The viscosity (or the silica content) of the fresh lava.

b) The gas-content of it.

\section{VAN BEMMEIEN'S SYSTEM.}

It is a table in which the different eruptions are classified as the function of the gas-content of the erupted magma on one hand and of the viscosity of it on the other (Table I).

Table I.

\begin{tabular}{|c|c|c|c|}
\hline \multirow{2}{*}{ Viscosity } & \multicolumn{3}{|c|}{ Gas-content: } \\
\hline & Low & Medium & Highı \\
\hline $\begin{array}{l}\text { Low (basic som- } \\
\text { position) }\end{array}$ & Javia slieets (A) & Strombolian (I)) & (Ytrian) (G) \\
\hline $\begin{array}{l}\text { Medium (intorme- } \\
\text { rliate composi- } \\
\text { tions) }\end{array}$ & Java tongnes (B) & Vulcanian ( $\mathrm{E}$ ) & P'linian (1I) \\
\hline $\begin{array}{l}\text { High (acirl com- } \\
\text { position) }\end{array}$ & $\begin{array}{l}\text { Ifuva plugs and } \\
\text { domes (C) }\end{array}$ & $\begin{array}{l}\text { Peléenn (nućes } \\
\text { artentes) (F) }\end{array}$ & Ignimbritie (I) \\
\hline
\end{tabular}


Van Bemmelen has mentioned that the so called Ytrian type (G) represents an exceptional case, namely the high gas-content was the consequence of the sulilen melting of an ice-sheet, under which a fissure-eruption had taken place. Also according to him the types $\Lambda$,

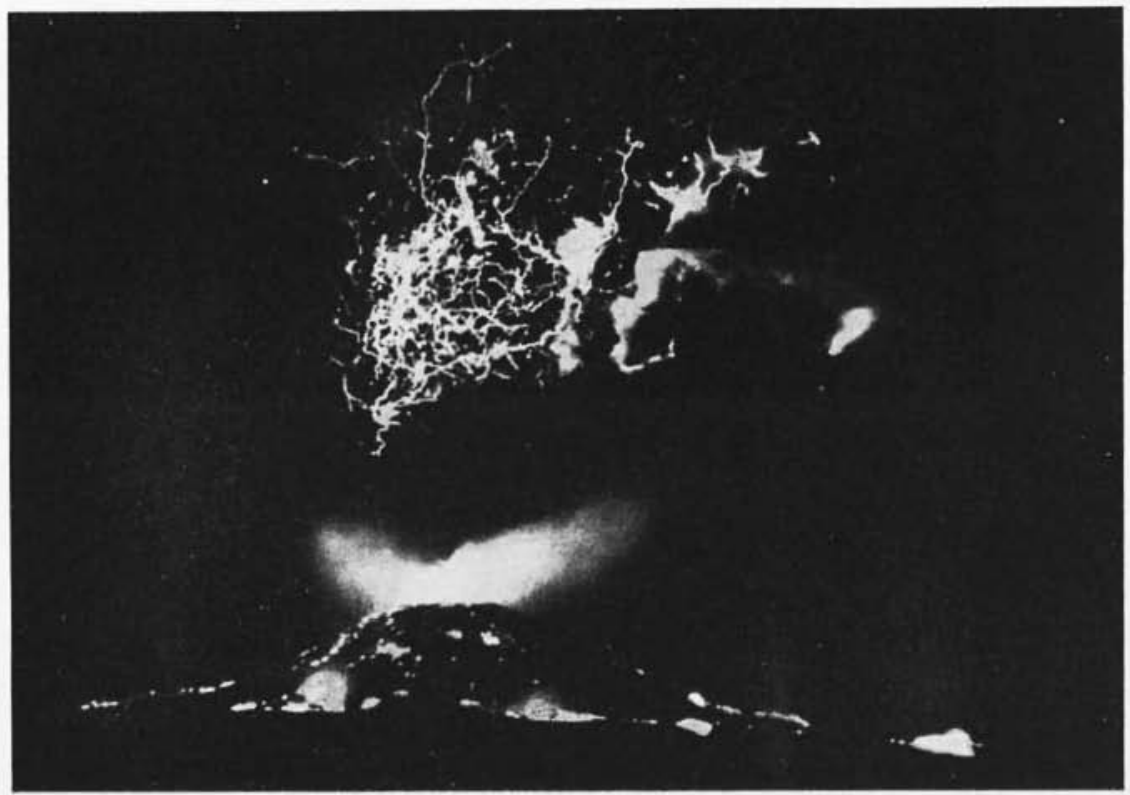

Photo 4 - Electrical phenomena during the eruption of Vesuv in 1944

$\mathrm{B}$ and $\mathrm{C}$ are non-explosive, but extrusive ones. The types $\mathrm{D}, \mathrm{E}$ and $\mathrm{F}$ are characterised by short explosive eruptions. Iastly, types $\mathbf{G}, \mathrm{H}$ and $I$ are characterised by great quantity of erupted magma and explosions of extreme violence. In types $H$ and $I$ the magma is transforming into tephra still in the depth, during the rising-process of the rock-melts. While in type II the eruption belches out the magma through a volcanic crater, in case of type I the magma reaches the surface generally throughout fissures. In case of type $\mathrm{H}$. the paroxysm takes place during the so called Perret-phase (gas-phase, see later), at the end of Plinian activity, during or after that a gravity slide (Vesuv, 79 A.D.) or a total collapse (Krakatoa, 1883) of the volcanic structure may occur. Also accorling to van Bemmelen, the Bronze Age ("Minoan") eruption of Santorin (between 1500 and 1400 , B.C.) belongerl to types $H$ and $I$. 
AUXULARY TABLES.

Owing to certain difficulties in the printing-technique, it is not possible to publish the author's new system as at table but only as a llawing (see Fig. I). It is necessary to supplement the respective drawing with some auxiliary tables, which contain some important features of the fundamental types (classes). The drawing (Fig. I) and these auxiliary tables must be used simultaneously (that is togfther). As a result of such a procedure we can obtain many further informative data regarding the volcano which is under consideration on the basis of its position in the new system.

The first auxiliary table is represented in Table II.

Table II.

\begin{tabular}{|c|c|c|c|}
\hline \multirow{2}{*}{ Viscosity } & \multicolumn{3}{|c|}{ Gas-content } \\
\hline & Jow & Medium & Higrh \\
\hline $\begin{array}{l}\text { Very low (ultria- } \\
\text { basice) }\end{array}$ & $\begin{array}{l}\text { Cltrabasic } \\
\text { ('lass (J) }\end{array}$ & & \\
\hline J.ow (basis) & $\begin{array}{l}\text { Isava Shoet } \\
\text { Class (A) }\end{array}$ & $\begin{array}{l}\text { Stromboliais } \\
\text { Class (J)) }\end{array}$ & \\
\hline $\begin{array}{l}\text { Hedium (inter- } \\
\text { mediate) }\end{array}$ & $\begin{array}{l}\text { Lava Tonrue } \\
\text { Class (B) }\end{array}$ & $\begin{array}{l}\text { Vulconian } \\
\text { Class (E) }\end{array}$ & $\begin{array}{l}\text { Plinian } \\
\text { Classi (II) }\end{array}$ \\
\hline IIiglı (acill) & $\begin{array}{l}\text { Iava Dome } \\
\text { Class (C) }\end{array}$ & $\begin{array}{l}\text { Peléean } \\
\text { Class (F) }\end{array}$ & $\begin{array}{l}\text { Ignimbritic } \\
\text { Class (I) }\end{array}$ \\
\hline
\end{tabular}

Comparing Table II with Table I, we cun state the fact that some alasses of the former (types $\Lambda, B, O, D, E, F, \Pi$ and $I$ ) are to be found in the latter, too. But type $G$ (Ytrian-type) now is absent, since it is only an exceptional case but not a real fundamental type. Its high gas-content - namely - was the direct consequence of a subglacial cruption. In the Nature the low viscosity and high gascontent don't exist together. Therefore we may regard the respective phenomenon, manifested itself in the case of the Ytri-eruption only as a pseudovolcanic one.

On the other hand we introduced a new class, namely the ultrabasic one $(J)$ - corresponding to Bullard's suggestion $\left(^{3}\right)$ regarding the 
Table III

\begin{tabular}{|c|c|}
\hline Viscosity & Low gas-contont \\
\hline Fory low & 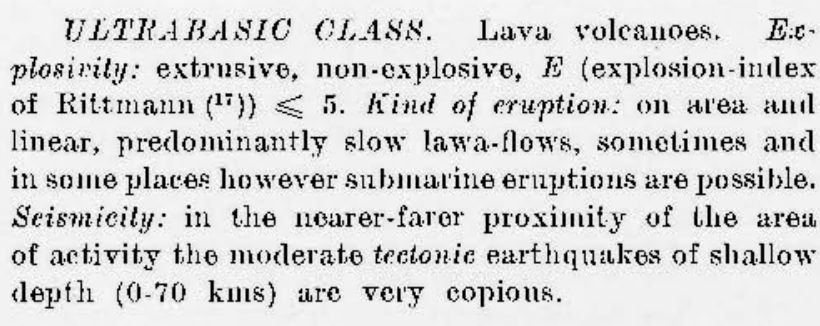 \\
\hline I.ow & 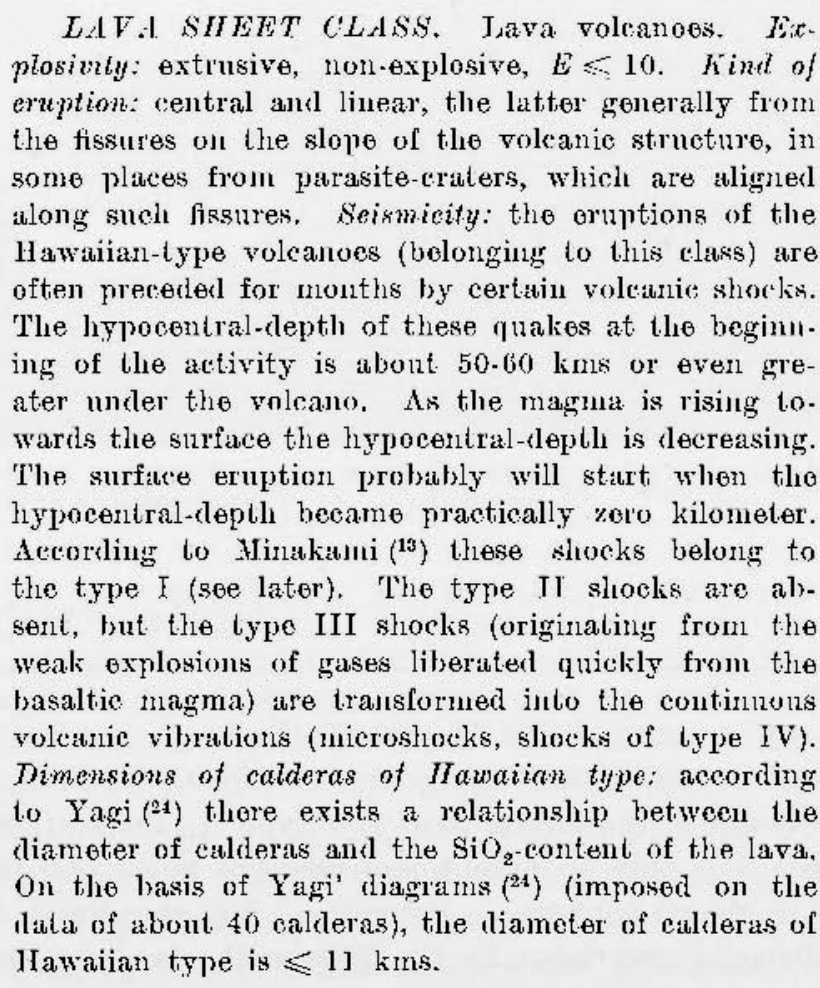 \\
\hline Merlium & $\begin{array}{l}\text { LATA TONGUE OLASS. Lava voleanoes. Fx- } \\
\text { plosivity: extrusive, non-explosive, } E \leqslant 10 \text {. Find of } \\
\text { eruption: central and linear. Seismicity: preslominiantly } \\
\text { volutulc microshocks. }\end{array}$ \\
\hline
\end{tabular}


Table III (cont.)

\begin{tabular}{|c|c|}
\hline Viscosity & Low gas-conteut \\
\hline $\mathrm{High}_{\mathrm{l}}$ & 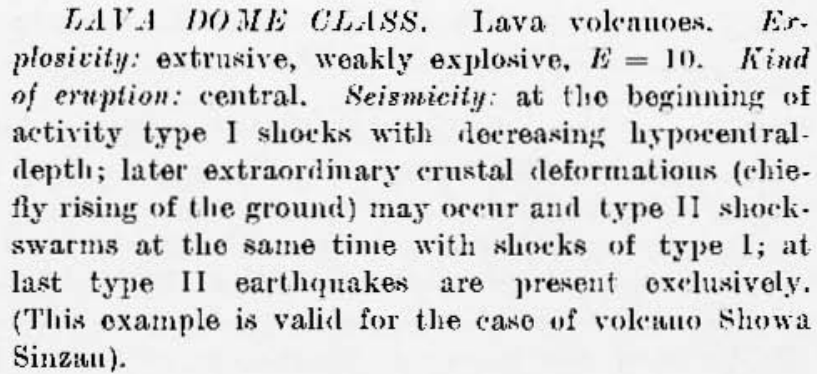 \\
\hline
\end{tabular}

Table IV.

\begin{tabular}{|c|c|}
\hline Viseosity & Merlium gas.content \\
\hline Low & 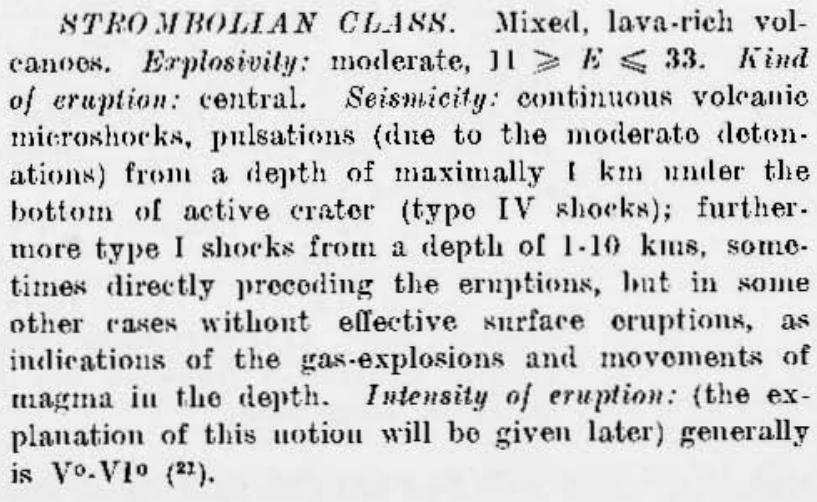 \\
\hline Metlium & 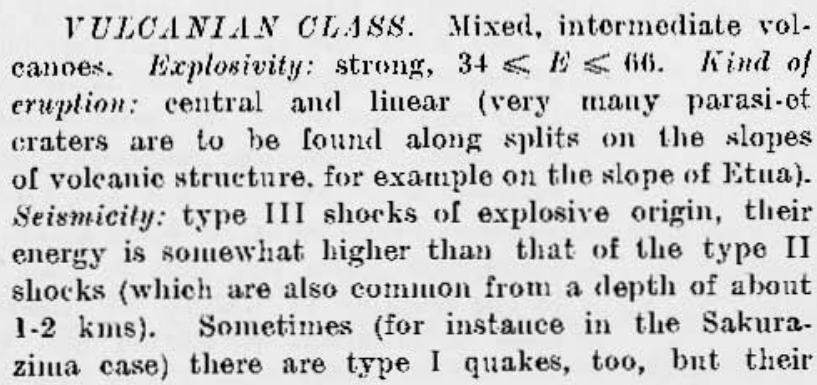 \\
\hline
\end{tabular}


Table IV (cont.)

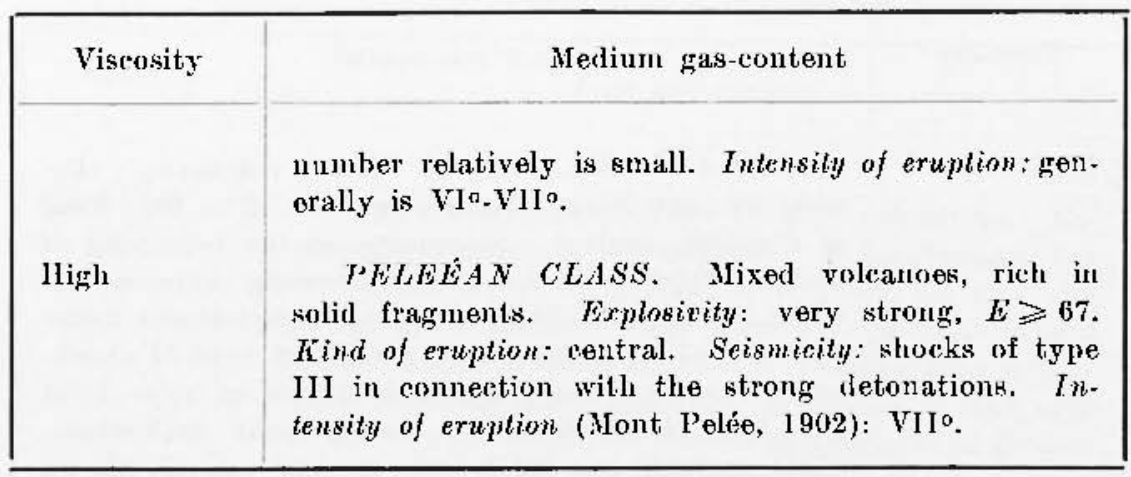

Table V.

\begin{tabular}{|c|c|}
\hline Viscosity & High gas-content \\
\hline Medinın & 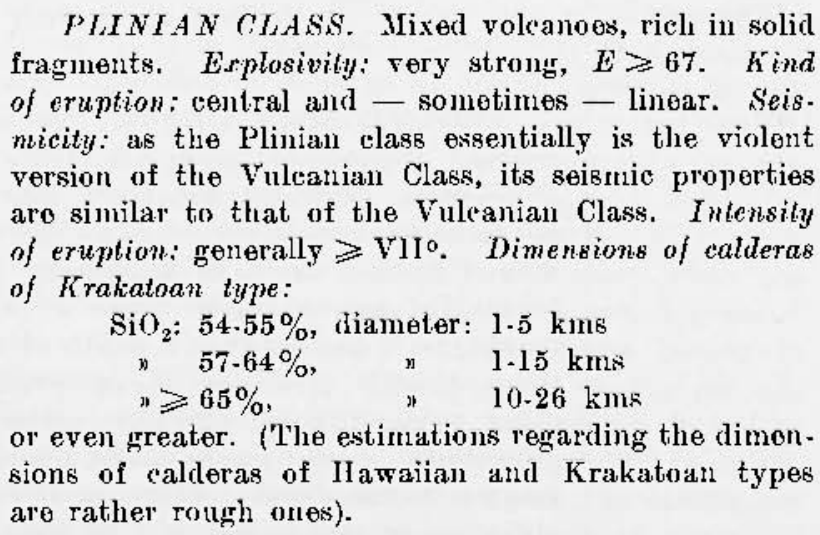 \\
\hline lligh & 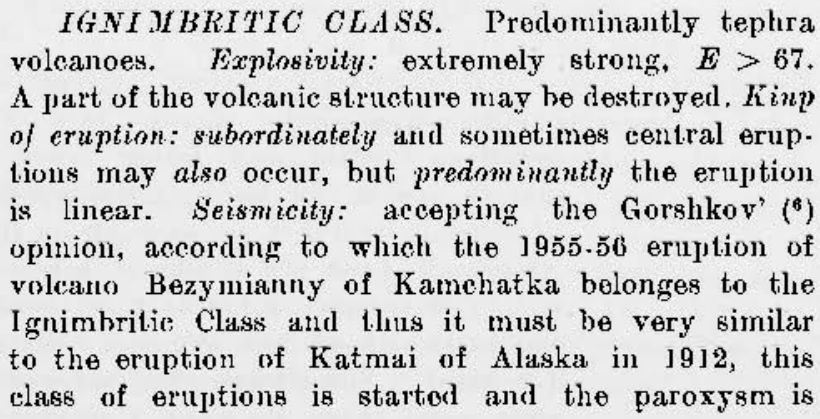 \\
\hline
\end{tabular}


Table $V$ (eont.)

\begin{tabular}{|c|c|}
\hline Viscosity & High gus-content \\
\hline & 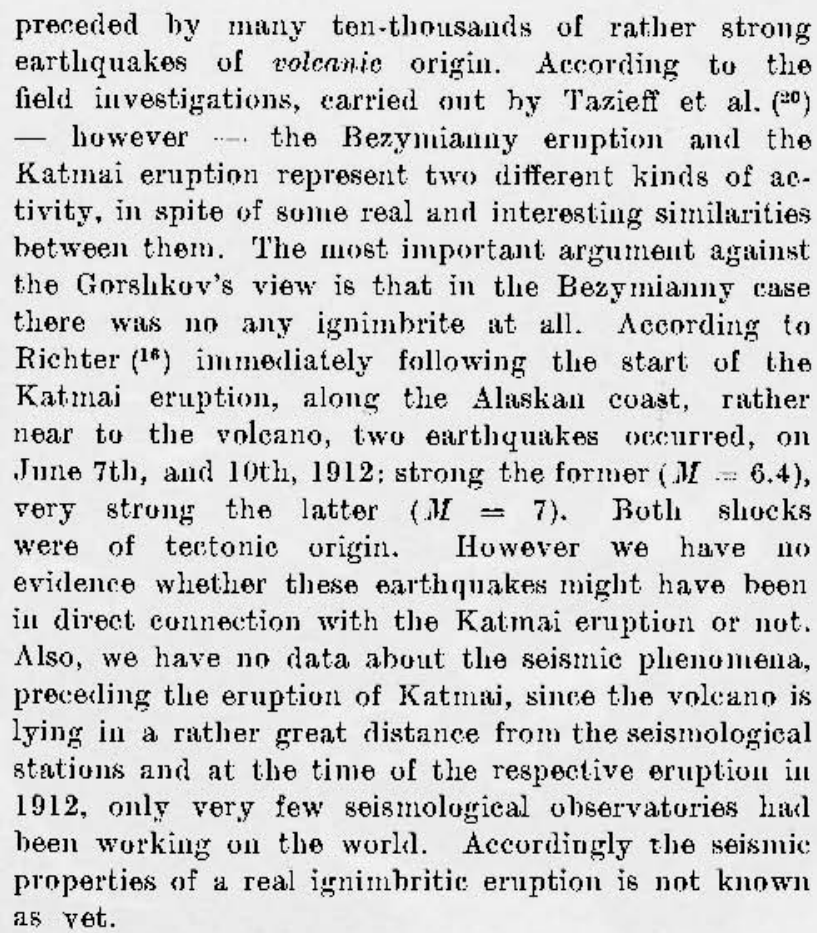 \\
\hline
\end{tabular}

introduction into the cathegories a type, he called as Icelandic onc. The Ultrabasic Class is characterised by a very low viscosity and a low gas-content.

Some important data concerning the new classes $(J, A, B, C, D$, $\mathrm{E}, \mathrm{F}, \Pi$ and I) are to be found in Tables III., IV and V, respectively.

\section{Phreatid and phientomagmatic eriptions.}

The exact definitions of phreatic and phreatomagmatic eruptions were given recently by Neumann van Padang (14). Accordingly: phreatic eruption is caused by the expansion of volatile matter above the roof of an igneous body. The ejecta blown out at relatively low 
temperature contain no fresh inculescent matter. However, in some cases fresh magmatic material may accompany a phreatic eruption.

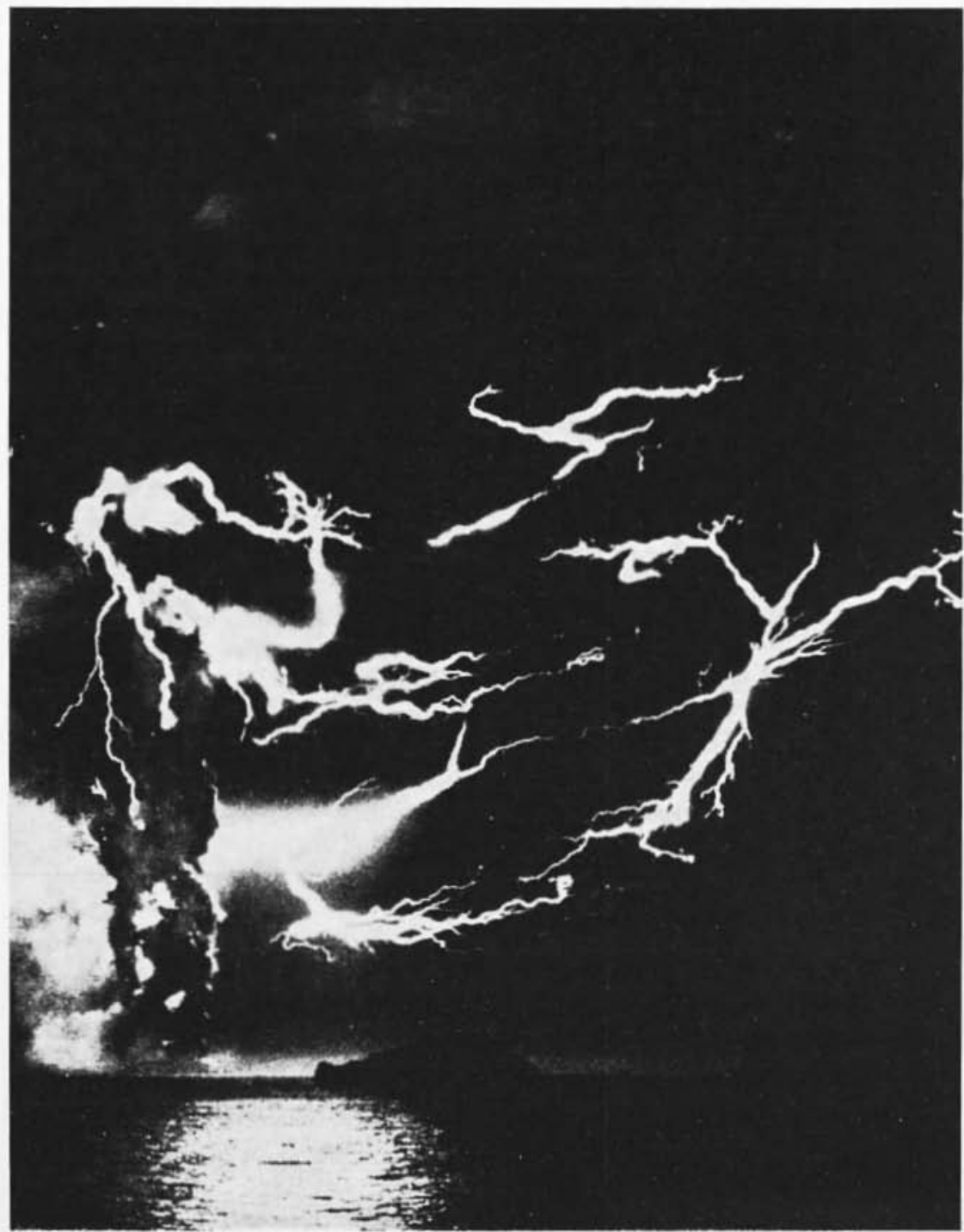

Photo 5 - Electrical phenomena during the birth of Surtsoy in 1963.

In those cases Stearns and HacDonald called the phreatommagatic eruptions. It is a volcanic eruption or explosion, ordinarily of extreme 
violence, produced when an ascending magma comes into contact with grownd water. Gssential as well as accessory ejecta are expelled. Such eruptions difler from typical magmatic explosions where the gases are chiefly derived from the magma (1-1) $[p p .660,661,663]$.

'Tahle VI.

\begin{tabular}{|c|c|}
\hline Viseosily & Medium or high sas-eontent \\
\hline Jetlium or high & 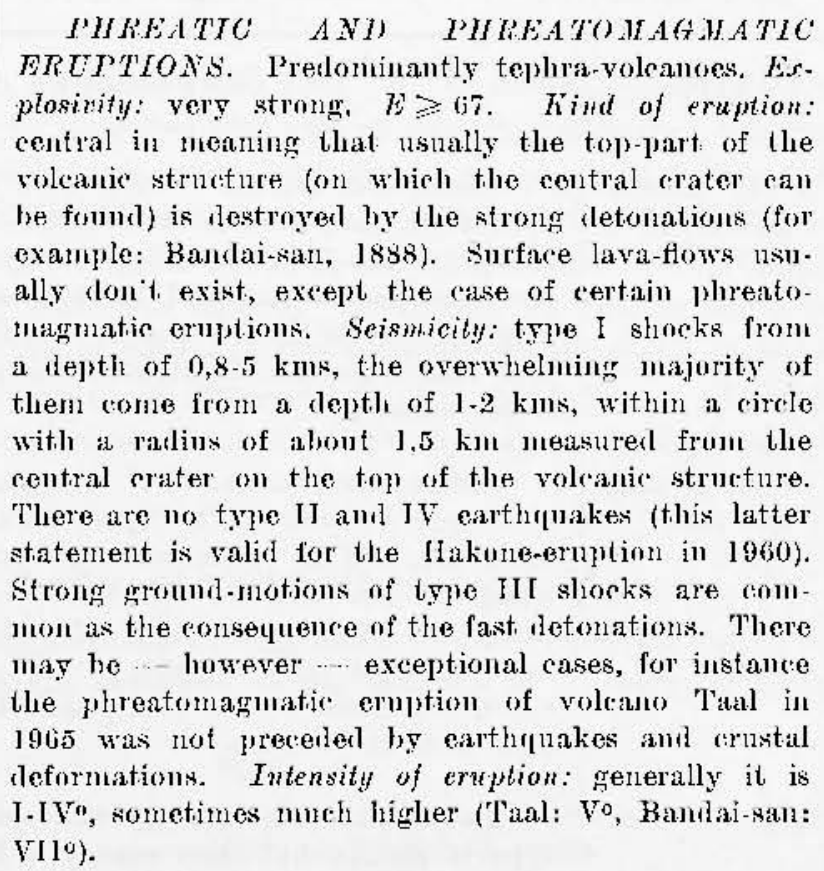 \\
\hline
\end{tabular}

In our system this kind of eruptions received the serial number 22. These eruptions represent such a case which has a position among four classes; namely phreatic and phreatomagmatic eruptionf may oceur alike in the cases of Vulcunian, Plinian, Peleean and Ignimbritic Classes. Furthermore, as we shall see in the detailed explanation of the system, there are some further types, in which the possibility of phreatic and/or phreatomagmatic eruptions exists.

In Table VI we gave a summary about the most important features of these kinds of eruptions. 
Type of voLCANIC SHOCKS.

It is noteworthy that in the original paper of Minakami (17) the signs of diflerent kinds of voleanic earthquakes were type $A$ and type B. The present author prefers the signs of type I, II, III and IV since the letters $A$ and $B$ it our present case mean two classes in the general system of voluanic activity.

Table VII.

\begin{tabular}{|c|c|}
\hline Type & Cllaracteristies \\
\hline $\begin{array}{l}\text { I (in Minaka- } \\
\text { "nii's paper }\left({ }^{13}\right): \\
\text { "A") }\end{array}$ & $\begin{array}{l}\text { Earthquake-swarms usually from a depth of } 1-10 \\
\text { kms, sometimes from } 20 \mathrm{~km} \text { and }- \text { rarely }- \text { from } \\
\text { a depth of } 50-60 \mathrm{~km} \text {. They have their origin from } \\
\text { the nass-movements and gas-explosions inside the } \\
\text { magma-chamber and voleanic elimney, respectively. } \\
\text { The epicenters are distributed on and around the } \\
\text { active erater. }\end{array}$ \\
\hline $\begin{array}{l}\text { II (in Minnka- } \\
\text { mi's paper(13): } \\
\text { " } B \text { ") }\end{array}$ & $\begin{array}{l}\text { Farthquake-swarms, but from a depth smaller } \\
\text { than type I shocks. The hypocentral-deptl is about } \\
0,1-1 \text { km. The opicenters are distributed unually } \\
\text { witlun a circle witl a radius of } 1 \mathrm{~km} \text {, mensured from } \\
\text { the center of active crater. They have their origin } \\
\text { from the explosions of gases as well as from the mo- } \\
\text { vement of magmatic masses, reached a very sliallow } \\
\text { levol from the surface. }\end{array}$ \\
\hline I11 & $\begin{array}{l}\text { Earthquake-swarms from the same depth as of } \\
\text { type II slocks, but their energy is higher than that } \\
\text { of earthquakes of type II. They are the direct con- } \\
\text { sequences of gas-explosions. }\end{array}$ \\
\hline IV & $\begin{array}{l}\text { Vibrations, pulsations of the ground, micro-earth- } \\
\text { quakes, tremors, due to the smaller but continuous } \\
\text { gas-explosions. Their epicenter is just on the bottom } \\
\text { of the active crater: it is the very strange case } \\
\text { when the opicenter and lypocenter are the same. }\end{array}$ \\
\hline
\end{tabular}

In Table VII we summarized the most important properties of these types of volcanic shocks. 
Tahle VIIl.

\begin{tabular}{|c|c|c|c|}
\hline \multirow{2}{*}{$\begin{array}{l}\mathrm{SiO}_{2} \text { content, } \\
\text { per cent }\end{array}$} & \multicolumn{2}{|c|}{ Period of type IV shocks in seconds } & \multirow{2}{*}{ Example } \\
\hline & a) siort period & b) long period & \\
\hline 40 & $0,3-0,5$ & & Syiragrongro \\
\hline $40 \%$ & 0,7 & & Kitzembanyi \\
\hline 47 & $0,5-0,7$ & $2,5-3,5$ & Kilanea \\
\hline 52 & $0,2-0,5$ & & Mihara-yama \\
\hline 53 & $0,3-0,5$ & & Aso-san \\
\hline $55-59$ & $0,1-0,2$ & $0,35 \ldots 0,6$ & Paricutin \\
\hline 60 & $0,25 \cdot-0,35$ & & Sakura-zima \\
\hline
\end{tabular}

According to Shimozoru and Berg $\left({ }^{18}\right)$, the microshocks, belonging to type IV, can be classified into two gromps, in accorlance with the length of their period. It seems that the length of perior is in a certain connection with the $\mathrm{SiO}_{2}$-content of the erupted lava and perhaps - at the same time with its temperature (Table VIII).

Disregarding from the case of Nyiragongo we can perceive the fact that the length of period of the mieroshoeks generally is decreasing with the increase of $\mathrm{SiO}_{2}$-content of erupted lava. Evidently it is in certain connection with the fact that the viscosity depends on the $\mathrm{SiO}_{2}$-content.

\section{IXTEXSTTY AND ENERGY OF ERUPTIONS.}

Is regards the intensity of ermptions we can refer to Tsuya (21), according to him the intensity is the function of quantity of ejecta (Table IX).

Tahle IX.

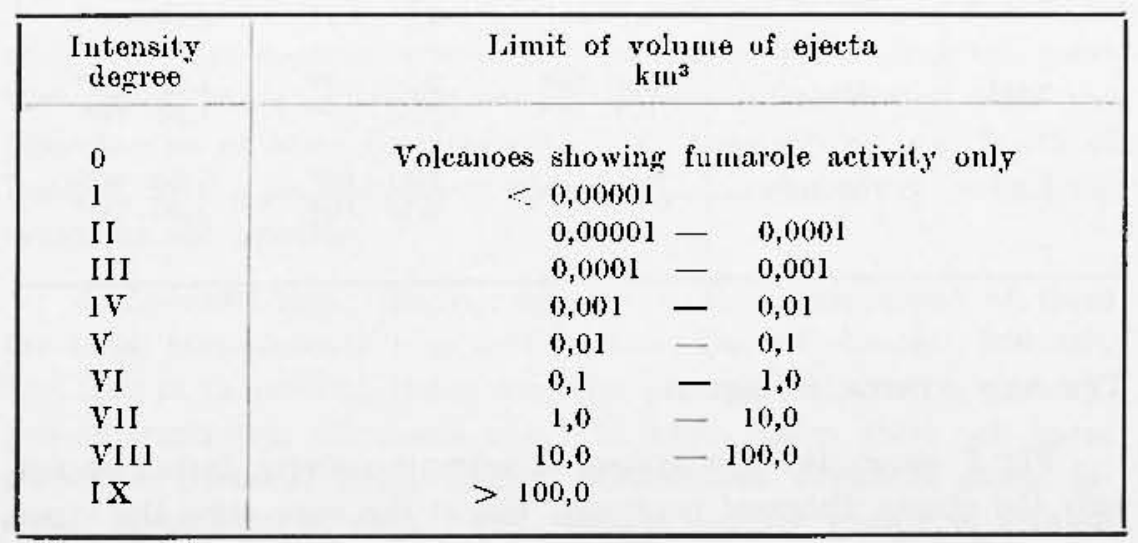


The author las established an empirical relationship between intensity and (thermic) cheryy of eruptions (9.10). On the other hand, Imbo (12) introluesl the notion of dynumic eruptione energy. The empirial connection among the intensity, dynamic aruptive energy and the lower and upper linits of thermic energy of the same eruption wan be found in Table $x$ (11).

T'able $\mathrm{x}$.

\begin{tabular}{|c|c|c|c|c|}
\hline \multirow[b]{2}{*}{$\begin{array}{l}\text { Intensity } \\
\text { regree }\end{array}$} & \multirow[b]{2}{*}{$\begin{array}{c}\text { Quantity of } \\
\text { lava or teplura } \\
\mathrm{mi}^{3}\end{array}$} & \multirow[b]{2}{*}{$\begin{array}{l}\text { 1)ynamic eru. } \\
\text { ptive eneriry if } \\
\text { the rensity is } \\
1.8 \text { gr-emb } \\
\text { orgs }\end{array}$} & \multicolumn{2}{|c|}{ Thermic energy, in ergs } \\
\hline & & & $\begin{array}{c}\text { in case of lava } \\
\text { volemoes }\end{array}$ & $\begin{array}{c}\text { in case of } \\
\text { vuleanues, the } \\
\text { ojeeta of } \\
\text { which pretomi- } \\
\text { nantly is tephrat }\end{array}$ \\
\hline I & $<10^{1}$ & $<0,8,10^{19}$ & $\begin{array}{l}5,25 \cdot 10^{14} \\
4,79 \cdot 10^{3}\end{array}$ & $\begin{array}{ll}1,00 \cdot 1010^{19} \\
1,00) \cdot 10^{20}\end{array}$ \\
\hline 11 & $101^{4}-100^{5}$ & $\begin{array}{l}\left(1,8 \cdot 10^{19}\right. \\
\left.1,8 \cdot 10^{0}\right)^{0}\end{array}$ & $\begin{array}{l}4,79 \cdot 10^{20} \\
4,37 \cdot 10^{21}\end{array}$ & $\begin{array}{ll}1,00 \cdot 10^{2 n} \\
1,00 \cdot 10^{21}\end{array}$ \\
\hline III & $10^{5} \cdot 10^{6}$ & $\begin{array}{l}0,8 \cdot 10^{20} \\
0,8 \cdot 10^{21}\end{array}$ & $\begin{array}{l}4,37 \cdot 11^{212} \\
3,98 \cdot 10^{22}-\end{array}$ & $\begin{array}{ll}1,00.10^{21} \\
1,100.10^{2}=1\end{array}$ \\
\hline $1 \mathrm{~V}$ & $10^{\mathrm{n}} \cdot 10^{7}$ & $\begin{array}{l}0,8 \cdot 10^{21} \\
0,8 \cdot 10^{32}\end{array}$ & $\begin{array}{l}3,98 \cdot 10^{2}= \\
3,63 \cdot 10^{=3}\end{array}$ & 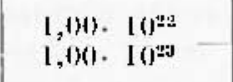 \\
\hline$r$ & $10^{7}-10^{3}$ & $\begin{array}{l}0,8 \cdot 10^{222} \\
0,8 \cdot 1\left(1^{23}\right.\end{array}$ & $\begin{array}{l}3,63 \cdot 10^{2:-1} \\
3,31 \cdot 10^{2-4}\end{array}$ & $\begin{array}{l}1,000 \cdot 1\left(0^{23}\right. \\
1,00) \cdot 1(1,24\end{array}$ \\
\hline VI & $10^{8}-10^{8}$ & $\begin{array}{l}0,8 \cdot 111^{23} \\
0,8 \cdot 10^{24}\end{array}$ & $\begin{array}{l}3,31 \cdot 10^{24} \\
3,12 \cdot 10^{25}\end{array}$ & $\begin{array}{l}1,(19) \cdot 10^{2-1} \\
1,(00) \cdot 10^{25}-\end{array}$ \\
\hline VII & $1\left(1^{9}-10^{10}\right.$ & $\begin{array}{l}0,8 \cdot 11^{22} \\
0,8 \cdot 11^{25}\end{array}$ & $\begin{array}{ll}3,112 \cdot 10^{25} \\
2,75 \cdot 10^{26}\end{array}$ & $\begin{array}{l}1,14) \cdot 10^{25} \\
1,14) \cdot 10^{28}\end{array}$ \\
\hline VIII & $10^{10} \cdot I^{112}$ & $\begin{array}{l}0,8 \cdot 10^{25} \\
0,8 \cdot 10^{26}\end{array}$ & $\begin{array}{l}2,7 \overline{5} \cdot 1\left(1^{23}\right. \\
2,51 \cdot 11^{22}-\end{array}$ & $\begin{array}{l}1,00 \cdot 11)^{26} \\
1,00 \cdot 10^{27}\end{array}$ \\
\hline $1 \mathrm{X}$ & $\mid 1^{11}-10^{12}$ & $>0,8 \cdot 11^{2}$ & $\begin{array}{l}2,51 \cdot 10^{27} \\
2,29) \cdot 10^{23}-\end{array}$ & $\begin{array}{l}1,00 \cdot 10^{27} \\
1,10 \mathrm{~J} \cdot 1\left(1^{23}\right.\end{array}$ \\
\hline
\end{tabular}

TIIE NEW SYSTEM IN JUETAIL.

Fig. I shows the new system of volcanic activity, including not only the classes discussed previously but at the same time the types 
as well as the transitional types, too. The two great arrows show the increase of explosivity (IXXP.).

Legend:

PA.PR.: Pacific province of rocks (some examples)

ATL.PR.: Atlantic province of rocks (some examples)

o: abyssal rocks

亏: eftusive rocks

$V_{i}$ : viscosity of erupted lava

VLo: very low

Lo: low

Me: medinm

Hi : higl

GC: gras-content of erupted lava.

A, B, C, D, E, F, G, H and I: types in van Bemmelen's system

ba: basic andesite, $\mathrm{SiO}_{2}: 54-57$ per cent

ia: intermediate andesite, $\mathrm{SiO}_{2}: 58-61$ per cent

aa: acid andesite, $\mathrm{SiO}_{2}: 62-65$ per cent.

Now let us go throughout the whole system begimning our way from the npper left comer of the Table, from type 1.

1. Rift-valley type. Very slow but continuous magma-flow from under the thin oceanic crust dluring millions of years along the great, Rift-valley, the axis of Mid-oceanic Rirlges, in connection with the phenomenon of ocean-floor spreading. In some places (e.g. South of Iceland, in the neighbourhood of volcanic island Surtsey) submarine eruptions are possible.

2. Icelandic type. Mighty lava-flows, the consequence of them are Iarge lava-plateaus (e.g. in Columbia, Paraná, Deccan, Iceland). The lava in the overwhelming majority is originated from a primary, non-difierentiated, ultrabasic one. In some places there are linear eruptions (Icelanil: Laki, Eligja, furthermore volcanoes along fissures: Katla, Hekla, etc.). The volcanic activity mainly is without 


\begin{tabular}{|c|c|c|c|c|c|}
\hline & & AT: & & & \\
\hline a & . $A$ & $\alpha$ & $B$ & si $0,1, \%$ & $P_{\text {oise }}$ \\
\hline & 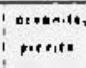 & & & 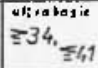 & $\leqslant \vartheta^{3}$ \\
\hline
\end{tabular}

\begin{tabular}{|c|c|c|c|c|c|}
\hline $\begin{array}{l}\text { pabtoro, } \\
\text { norile. }\end{array}$ & 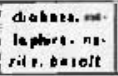 & $\begin{array}{l}\text { milsourite. } \\
\text { inoille }\end{array}$ & 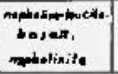 & $\begin{array}{r}\text { Lagic } \\
\geq 42, \leq 53 \\
\end{array}$ & $\pi 0^{4}-n^{2}$ \\
\hline
\end{tabular}

\begin{tabular}{|c|c|c|c|c|c|}
\hline $\begin{array}{l}\text { denite, } \\
\text { sisniles }\end{array}$ & 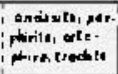 & mephlime-ket & phomese & 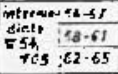 & $70^{6}-10^{7}$ \\
\hline
\end{tabular}

\begin{tabular}{|c|c|c|c|c|}
\hline 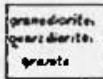 & 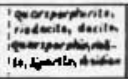 & ? & $\begin{array}{l}\text { acidic } \\
\geqq 66 \text {, } \leqq 77\end{array}$ & 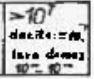 \\
\hline
\end{tabular}

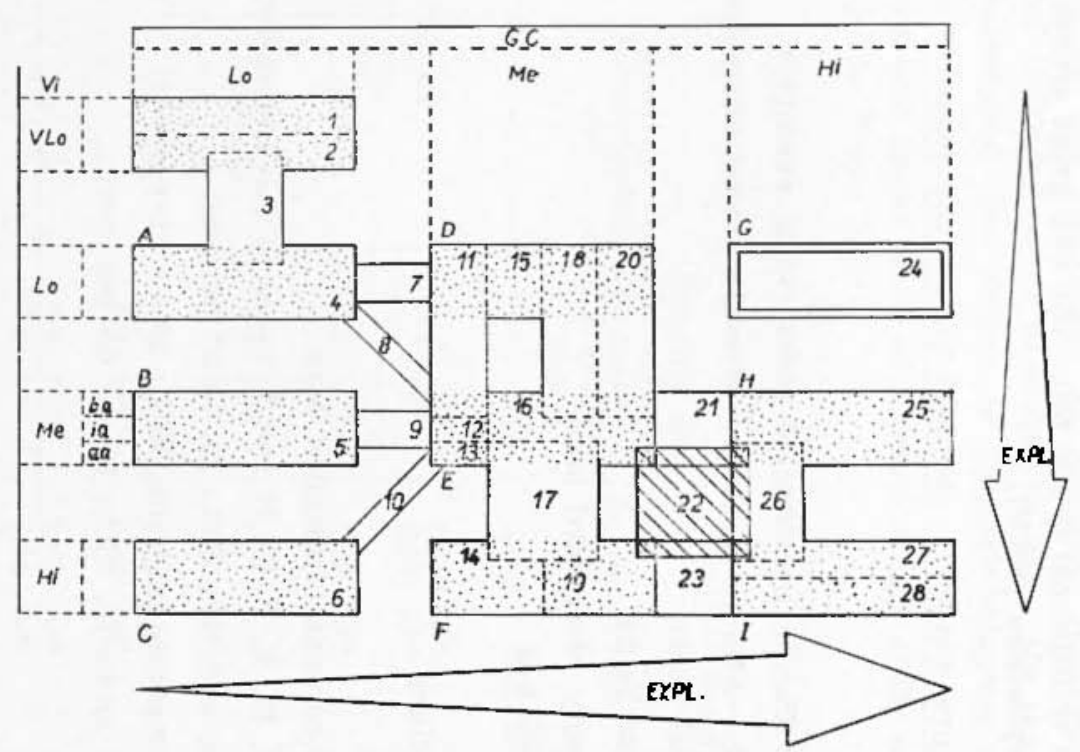

:

Fig. I - The new system of volcanic activity. 
explosions or is with weak or moderate explosions; however the Heklat harl such kind of eruption when its explosivity-index reached the value of 39 and the $\mathrm{SiO}_{2}$-content of its lava had been $58-60$ per ecnt, thus the lava was anlesite-like temporarily.

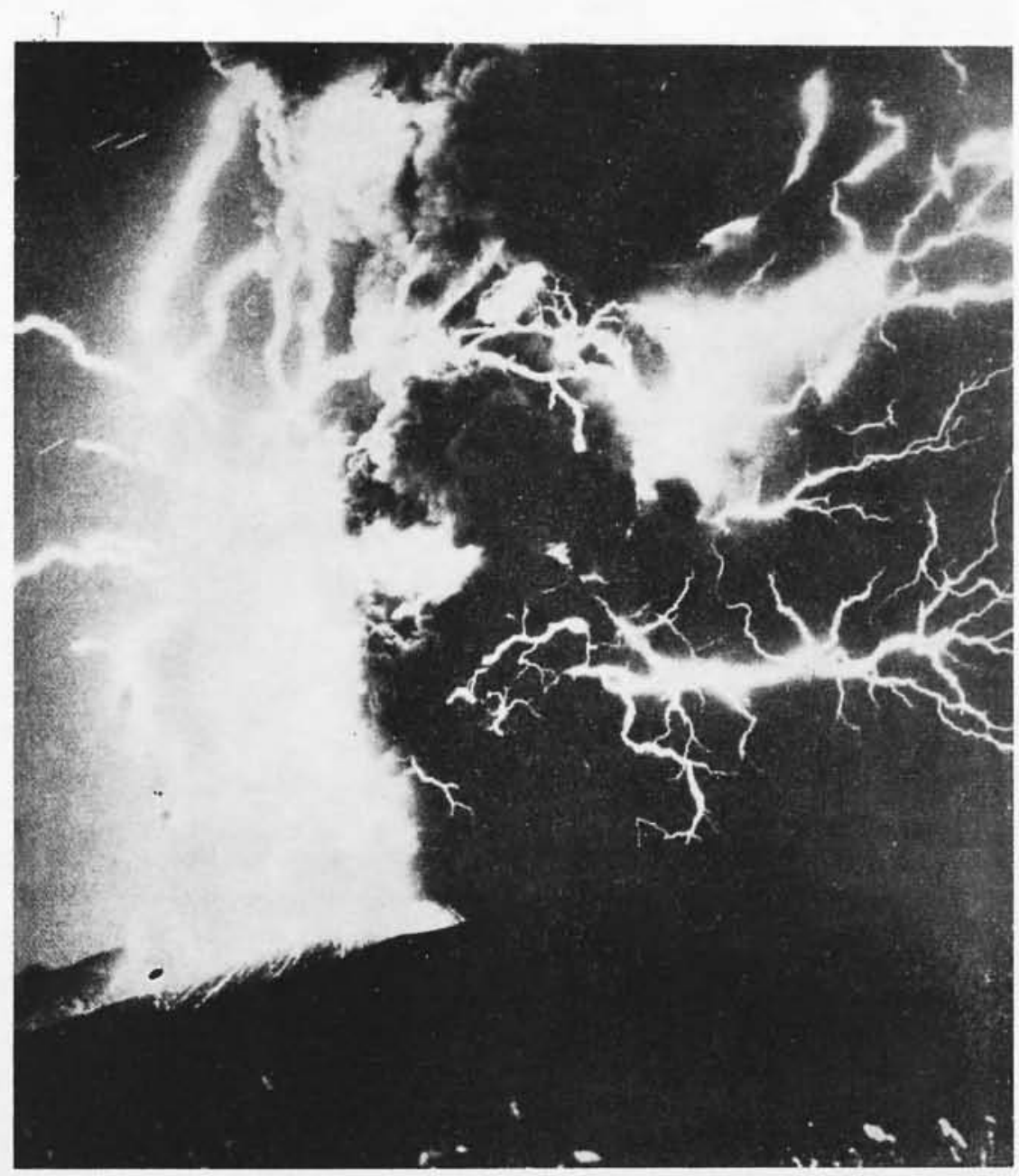

Ploto 6 - Electrical phenomena during the eruption of Cerro Negro of Nicaragua in 1971: it is surprisingly similar to that of Surtsey. The ploto has been made by Ingeniero Franco Penălba Estuelios Penälba Nicaragua (Special Report of Center for Short-Tived Phenomena. Smitlisonian Institution, written by J. G. Viramonte, E. Ubeda and M. Martinez, April 15, 1971. 
3. Lava-late type. Basaltic lava, very fluid, on the surface of which thin crust may exists temjorarily. Great lava-fountains may ocour. "Peles's lanir" and "tear". Very moxlerate explosivity. Fxamp]es: Halembatuatu, Nyiragonero.

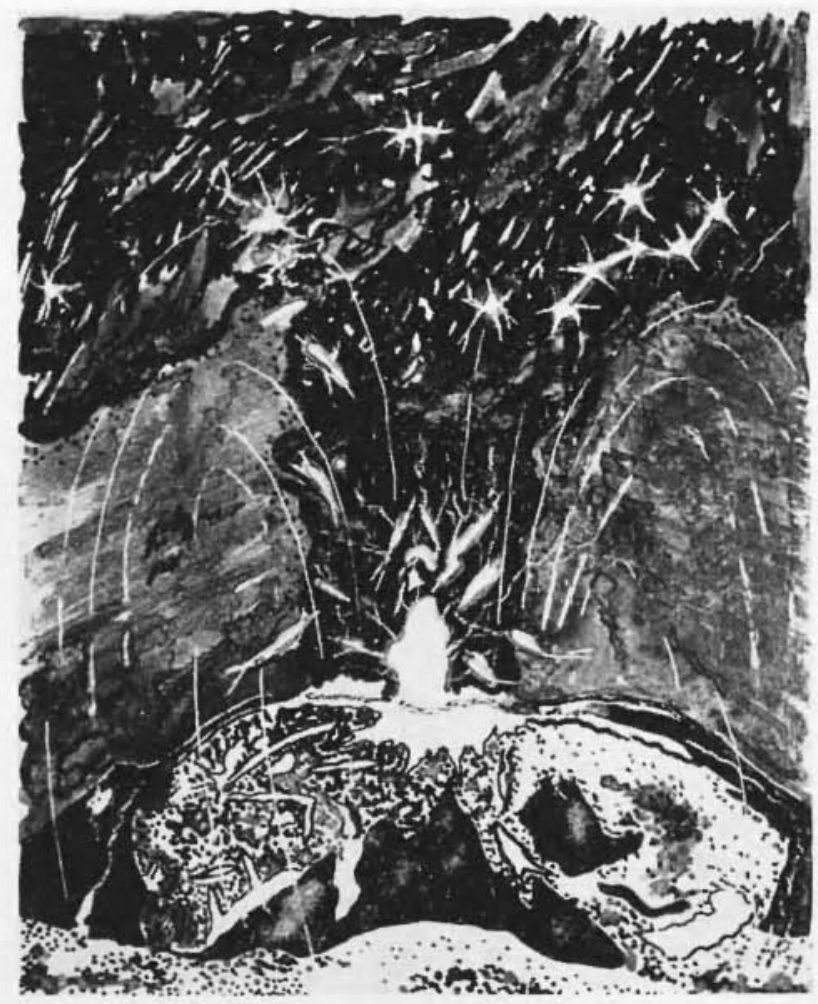

1) rawiug 11

4. Hawnitan type. It is identical with the Lava Sheet Class (see in Table III). Very fluid lava, the speed of which on the flanks of the volcanic structure may reach the value of $40-50 \mathrm{kms} / \mathrm{hour}$. The gases can liberate from the lava quickly and casily. Lava-fountains. There is none formation of ashes and scoriae, or if there is, it is only in a very small amount at the vent of the crater. The duration of erujotions may vary from some days to many months. Shield-voleanoes. Examples: Hauma I,oa, Mauna Kea, Kilauma. 


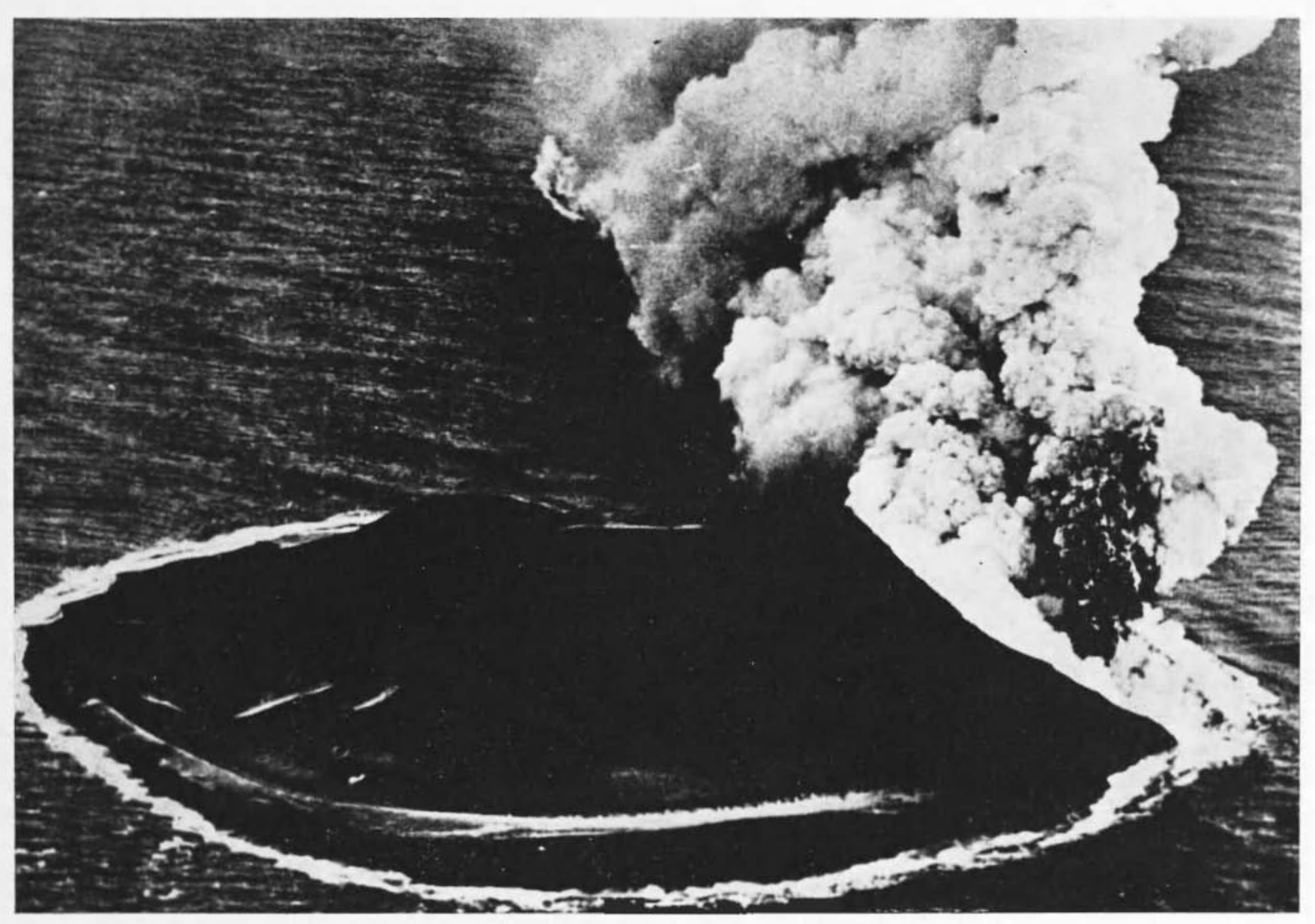

Photo 7 - The cone of Surtsey, originated by submarine activity. 
5. Lava-tongue type. It is identical with the Lava Tongue Class (see in Table TII). Less fluid lava with medium viscosity, usually solidifies in the valleys thus forming there a lat tongue. Similar, subsequent lava-flows on the same place of the respective valleys may lead to an inversion of the relief $\left(^{(}\right)$. Classical example: the extinct voleano Mount Egmont, New Zealand.

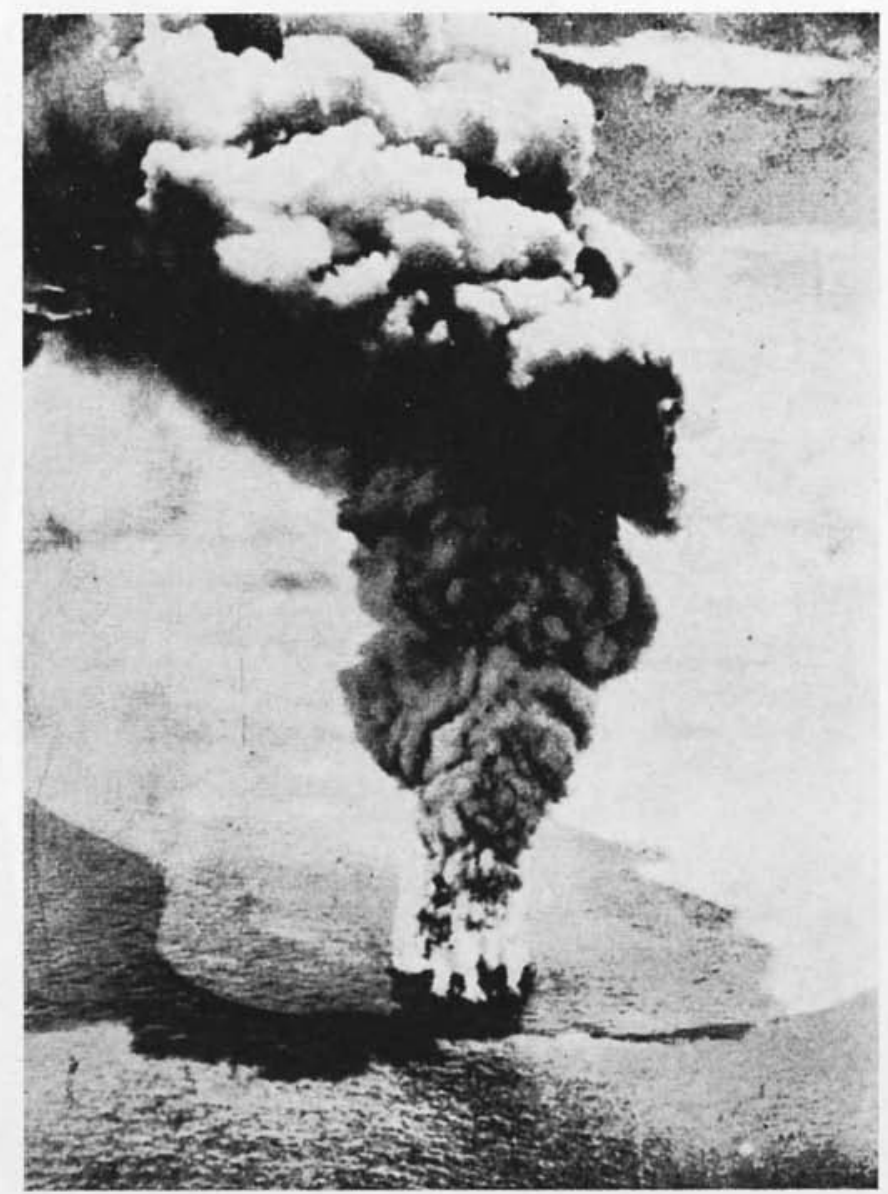

Photo 8 - Suhmarine eruption in the Pacific Ocean (Myoozin, 1952).

6. Lava-dome type. It is identical with Lava Dome Class (see in Table III). The erupted lava is very viscous. Inside the crater there originates a lava-dome, the dimensions of which are increasing with time. Example: Showa Sinzan, Japan. 
7. Mihara-yama type (on the basis of its aetivity in 1950-51). Weak explosions, the quantity of scoriae, ashes and bombs is moderate. From time-to-time the character of activity is purely Hawaiian, in otlere times it is typically strombolian.

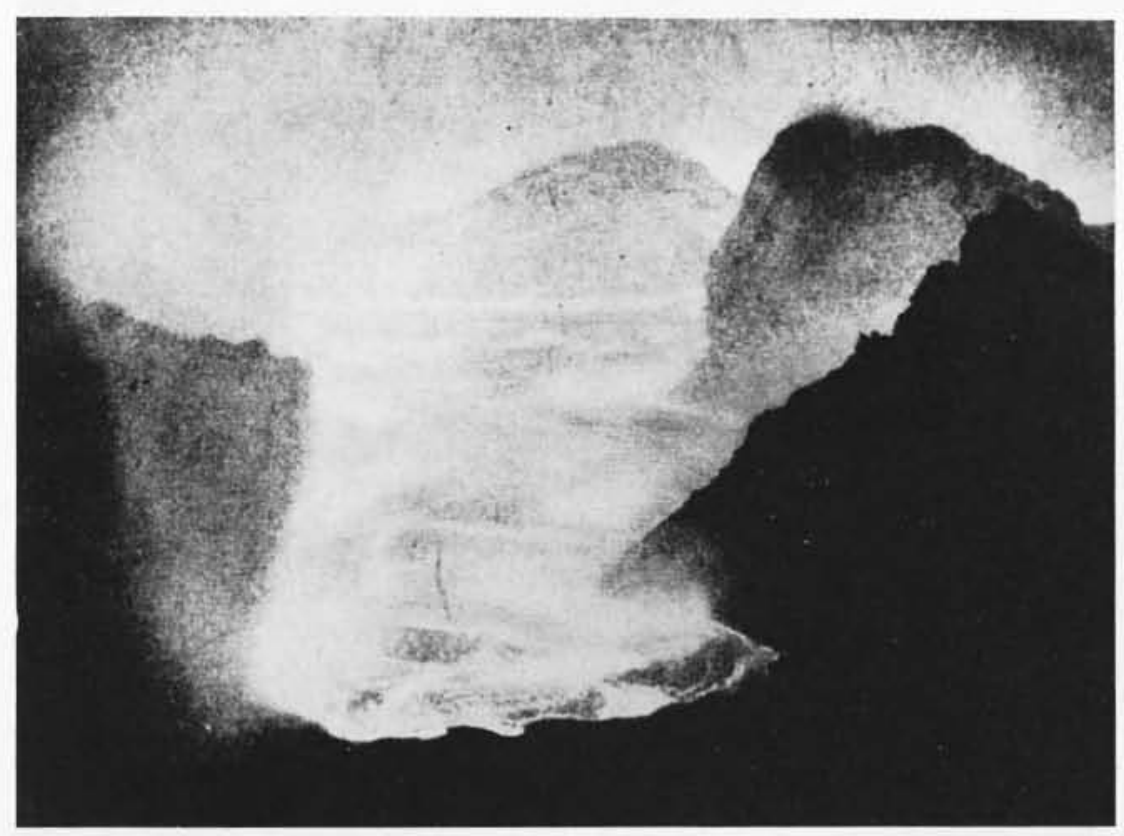

Photo 9 - The Halemamman lava-lake at Hawaii.

8. Polsky Tolbashik type. This volcano of Kamchatka often has a Hawailan activity, however on its slopes there are many active parasitic (secondary) craters, similar to the case of Etna.

9. Alphonsus type. In 1956, D. Alter has observed a gas-emission in the ring-mountain Alphonsus of the Moon. On the night of November 2, 1958, N. Kosyrev has observed a real voleanic eruption at the central peak of Alphonsus. At first, as lie observed, the central peak became deep-red — the cause of this phenomenon probably was the scattering-process of red-hot volcanic ashes and small fragments and later the central elevation of the respective ring-mountain became suddenly unusually bright. According to the photo-spectral investigations, carried out during these phenomena, there occurred an emission of $\mathbf{C}_{2}$ gases. H. P. Wilkins, founder and first president of Inter- 


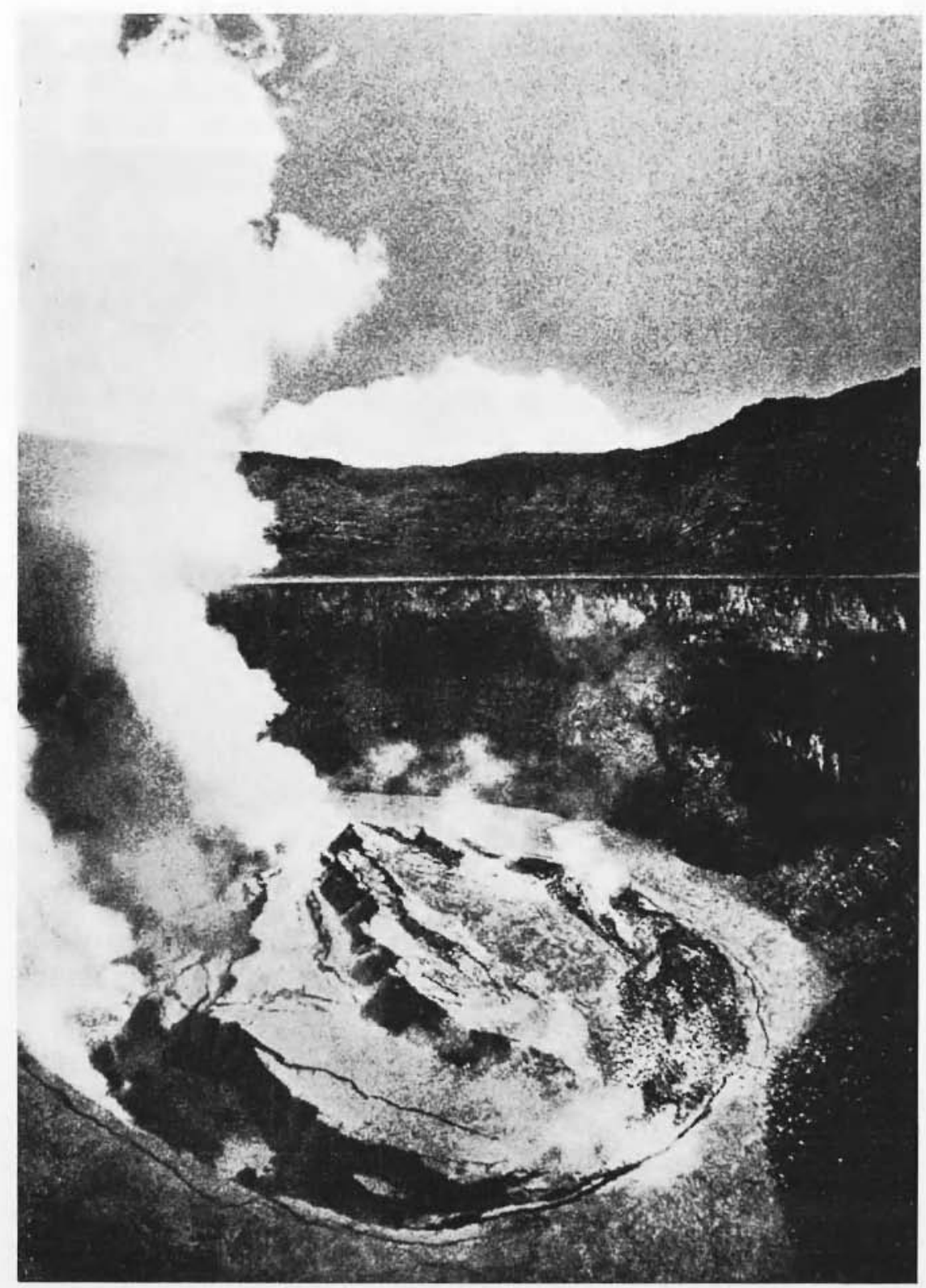

Photo 10 - The lava-lake of Nyiragongo in Africa. 
national Lunar Society reported later, that after the above mentionerl events on the Moon, he dikcovered a new, elliptical or circular roddish spot with a dinmeter of $2-3$ kns at the foot of the central cone of $\mathrm{Al}$ phonsus. This observation lad been confirmed later by otler explorers, the more, in later ycars some further gas-emissions and new roulish spatches were also observed. Similar reddish spots harl been obsarverl later in other craters of tha Joon, too.

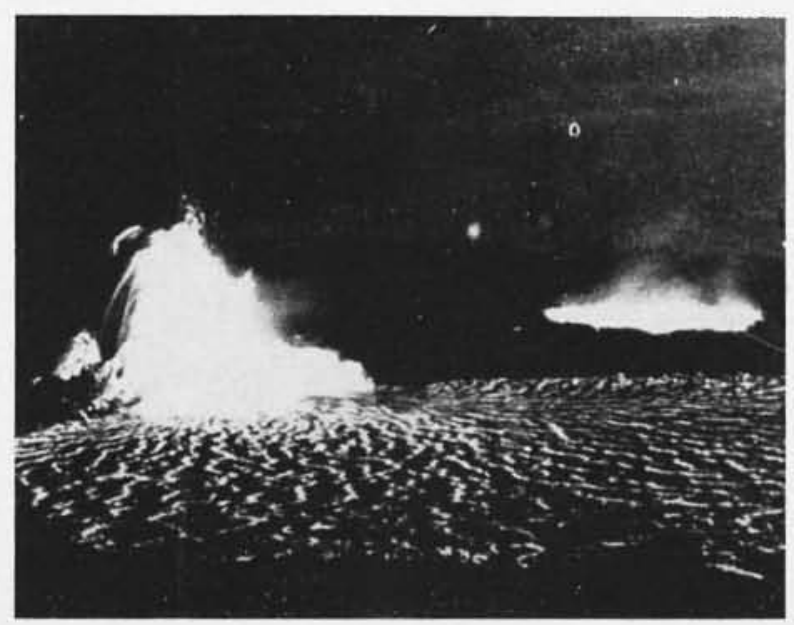

Photo 11 - Lava-flow and fountain on the flank of Mihara-yama. (Japan in 1951).

Accorling to Kosyrev the quantity of eseaper gases at the obscrvenl eruption of Alphonsus in 1958 might have been very small. It was estimated by him to be about $L(\mu) 0(\%) \mathrm{m}^{\text {al }}$ only.

The area, on which one ran find the ring-monntain Alphonsus, is a continental-like one, the surface rocks of which belong to the intermediate class between the basic and acid rock-categories.

The lava-spot, observer by Wilkins, dirn't flow too far from the artive vent or crater. Therefore we may suppose that it might have had a chameter similar to the lava-tongues. Areordingly the Nphonsus type may be regarder as a transitional one between type 5 (lava-tongue) and type 12 (Asama-yama).

It is noteworthy that since these classical first olservations of the activity of a lumar voleano, it came into light that the "volcanic" or "transient" Lunar phenomena (TLP or $L T P$ ) are rather frequent 
ones on the surface of the Hoon. The transient lunar phenomena can be regarded as:

a) lava andior pyroclastic-Hows with small amount (reddish syatches);

b) gas emissions;

r) scattering of ashes, lapillis and bombs;

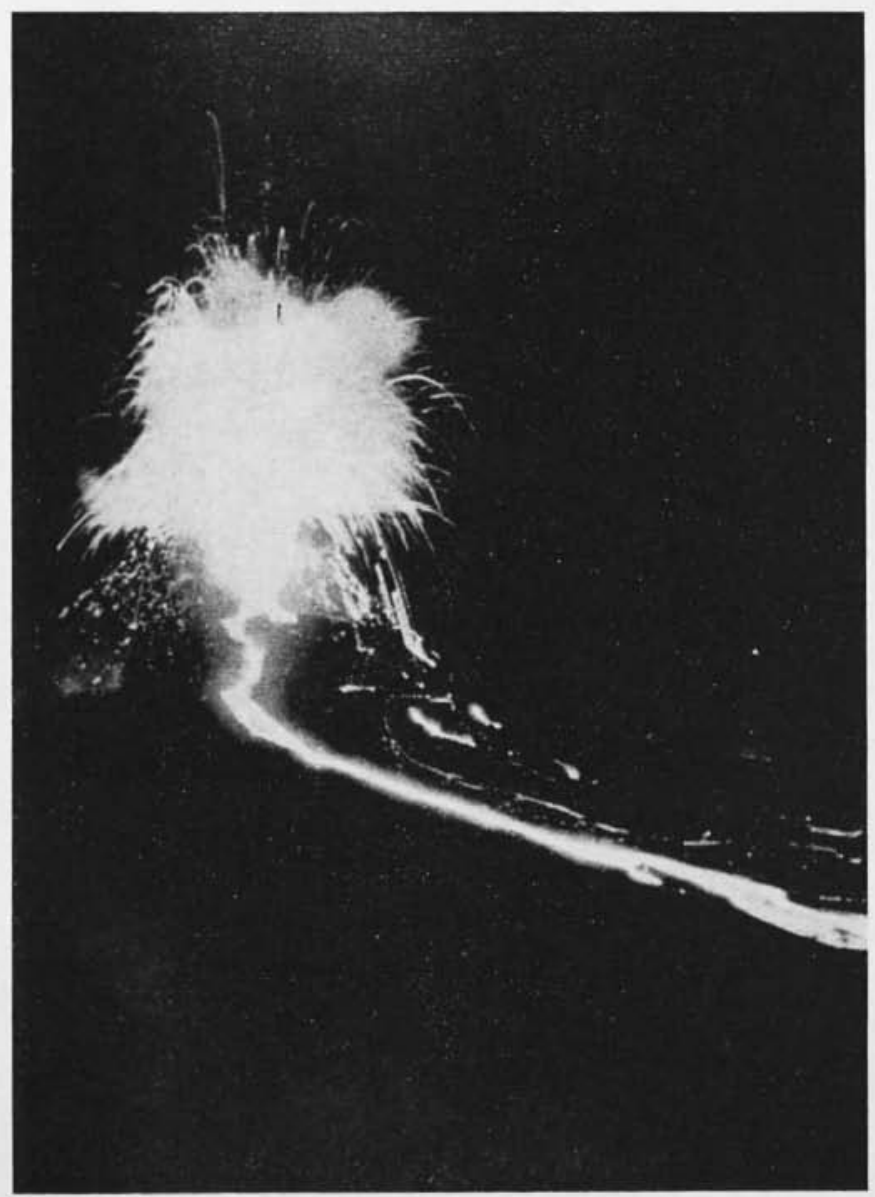

Photo 12 - Java-flow and glowing fragments at the Nyamlagira, Africa (after Tazieff).

all of which belong to the eategory of volcanic and/or postroleanic events. 
10. Shin Iojima - Mjojinshn type. Both volcanoes were submarine ones near Japan; the former erupted in 1934-35, the latter in

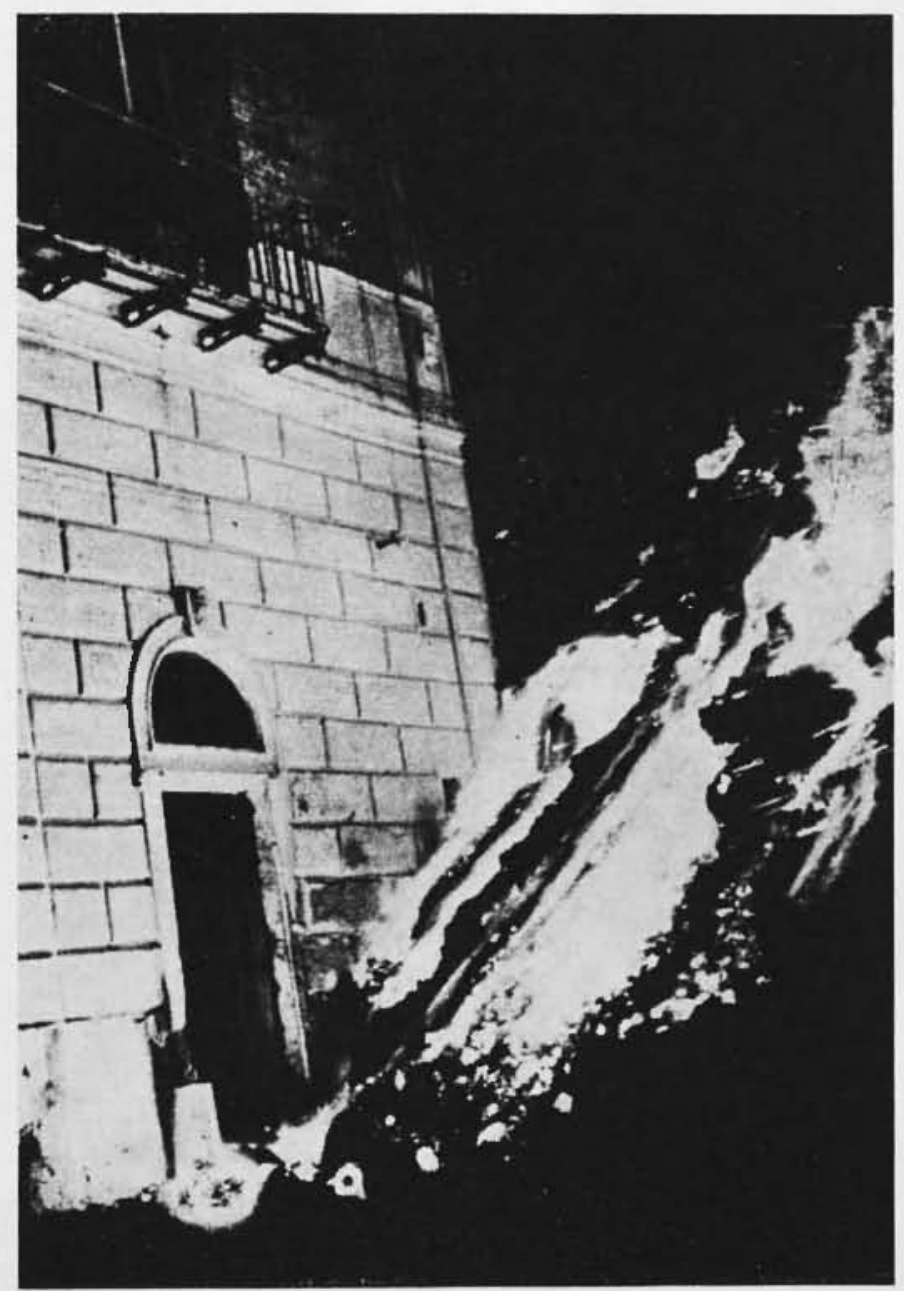

Photo 13 - The lava reaches the houses of San Sebastiano during the eruption of Vesuv, 1944 (after Imbo).

1952. Fxplosive eruptions, followed by the origin of submarine lavadomes, made up by acid andesite or dacite. Great quantity of pumice on the surface of the open water. 


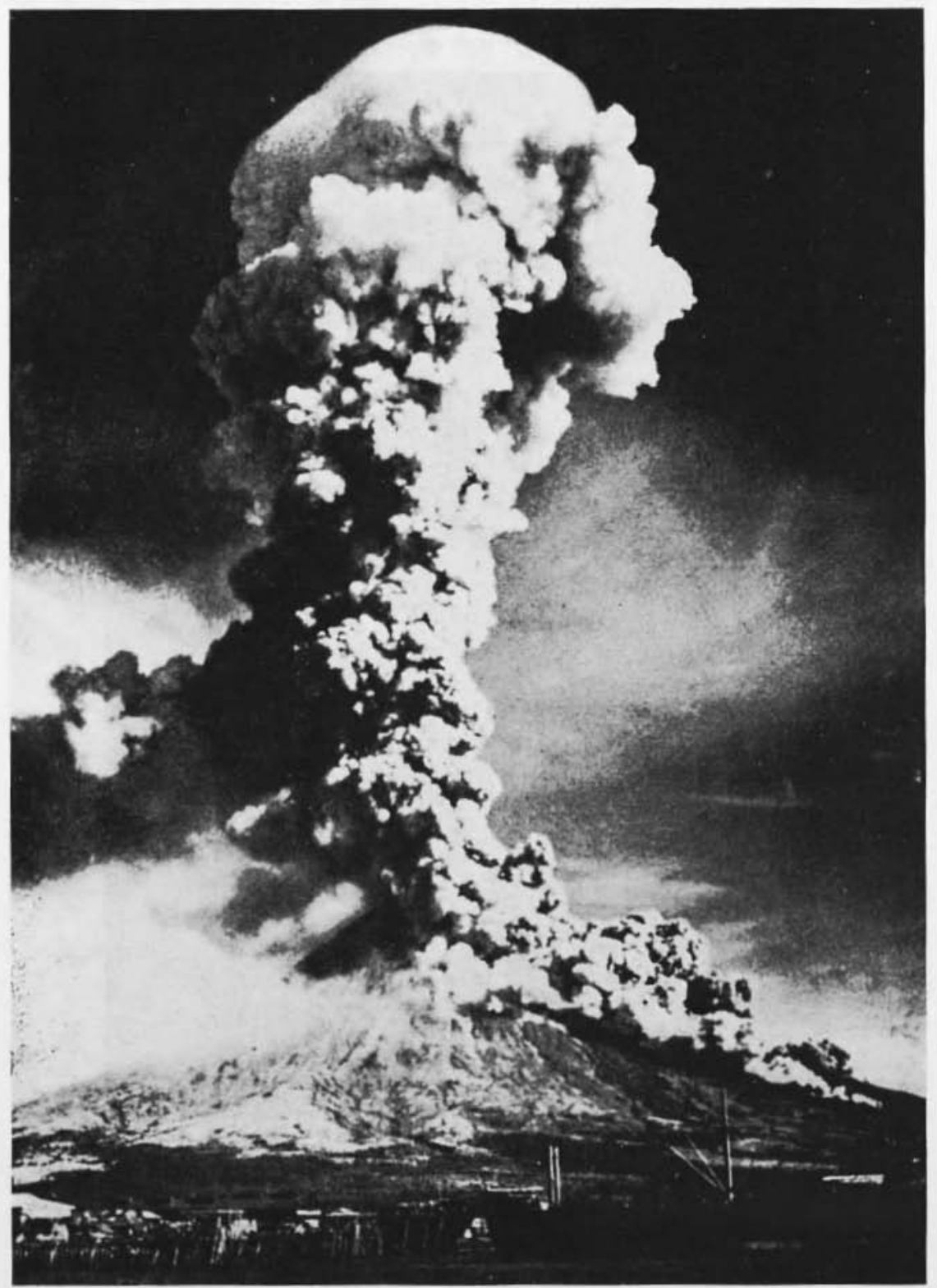

l'hoto 14 - Fruption-cloud of Mayon (Philippines) in 1938. 
11. Tori-shimn type. It is a transitional type between the Strombolian Class and the Volcanian ('lass. The lava is basaltic or basicandesitic. Explosive character, with many bombs, scoriae, ashes and pyroclastic-llows. Examples: Tori-shima (1939), Miyake-zima (1940) and some phases in the activity of Hilhark-yama in 1950-51. All mentioned examples are Japanese.

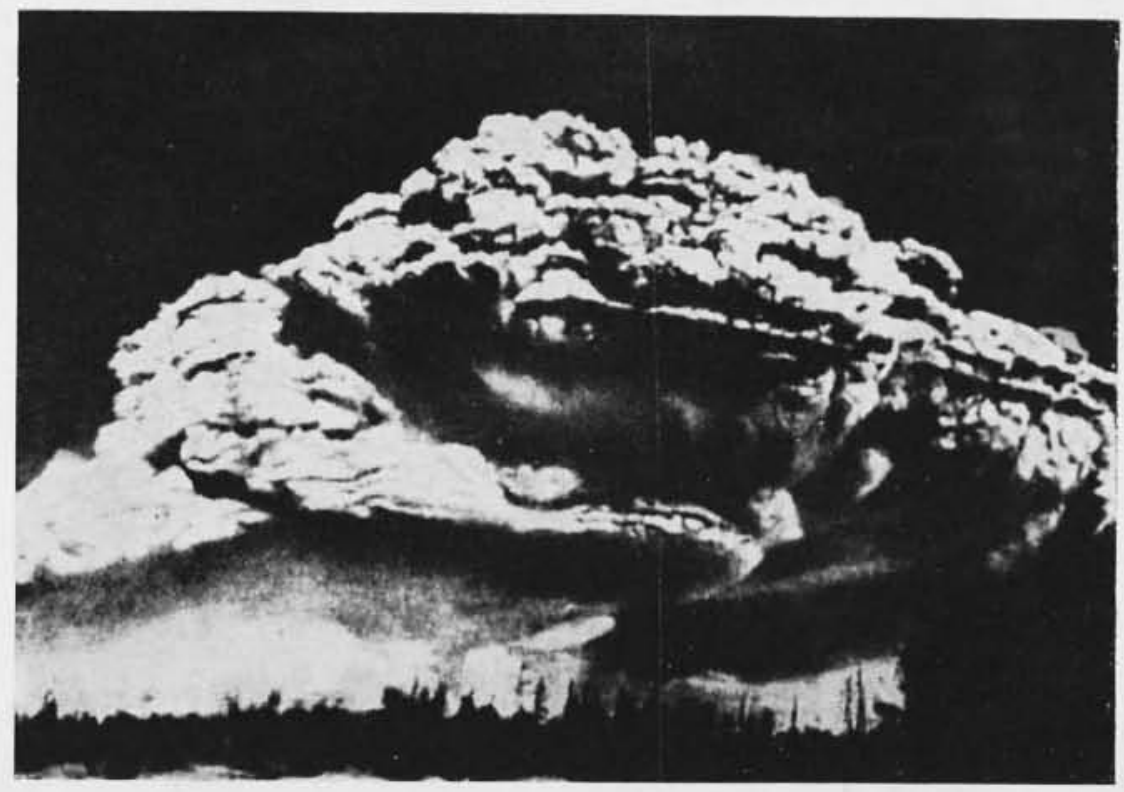

Plinto 15 - Flie $30 \mathrm{~km}$ high eruption-eloud of Bezymianny (Kamchatka) in 1956 (after Gorslıknv).

12. Asama-yama type. It is in a close relationship with the Vulcanian Class. Its lava is transitional andesitic. Iava-flows and pyroclastic-falls as well as pyroclastic-flows. Strong explosivity. Dark ashes-clouds with an height of 1000 metres or more; inside the clouds strange electrical plienomena may occur. Great quantity of pumice. Examples: Astama-yama (1783), Sakura-zima (1914 and 1946), both are Japanese voleanoes.

13. Tarumai-san type. It is also in close relationship with the Vulcanian Class and at the same time it is in a somewhat farther relationship with the Lava Dome Class. It differs from types 11 and 12 in the meaning that in its case, - following the explosive erup- 
tions - there is a possibility for the origin of clomes of acid andesite. Pyroclastic-flows and -falls are also possible. Example: Tarumai-san of Japan in 1909 .

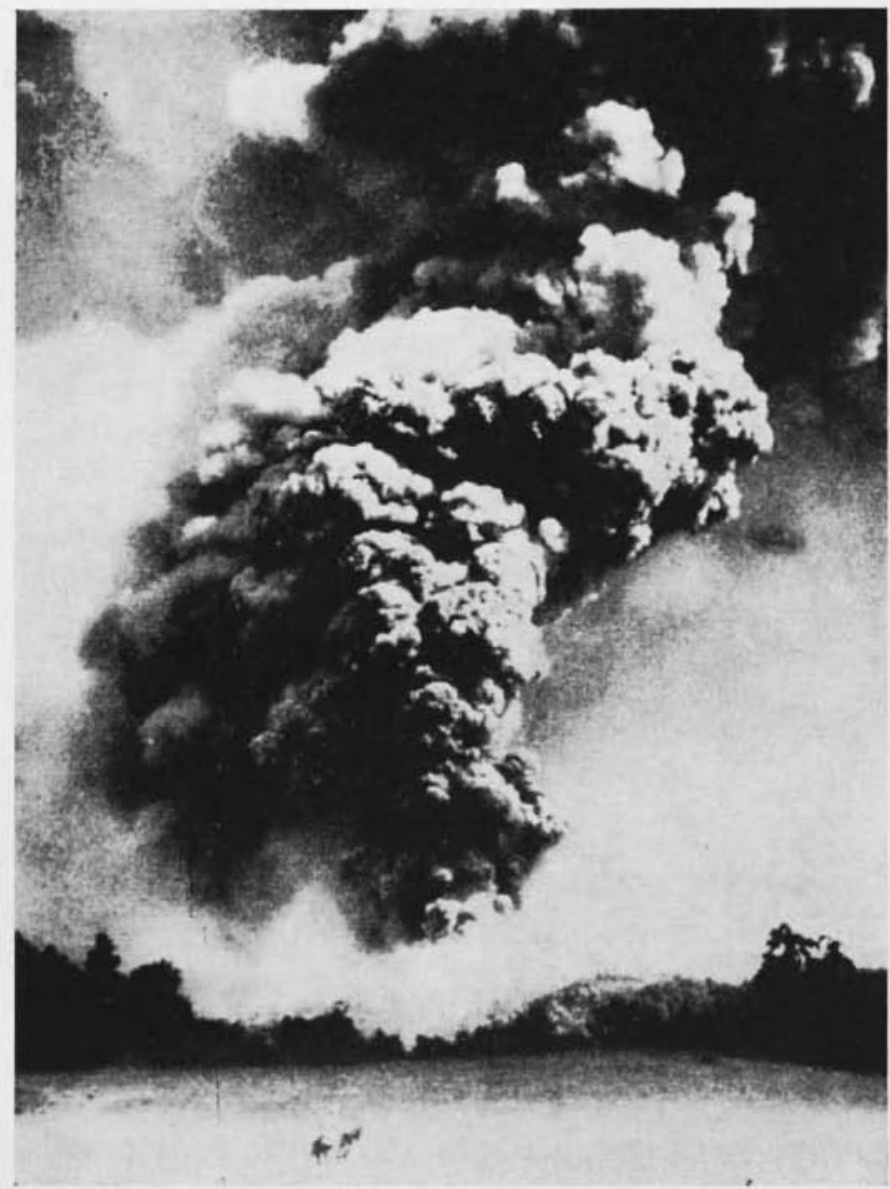

P'hoto 16 - The hirth of Purieutin (Mexico; 1943).

14. Merapi type. In very close relationship with the Peleean Class. Very strong explosive activity, swelling dlome from a very viseous, usually dacitic lava.

Subtypes:

a) glowing avalanches of explosive origin;

b) glowing avalanches of collapse origin;

c) glowing avalanches of complex explosive-collapse origin. 


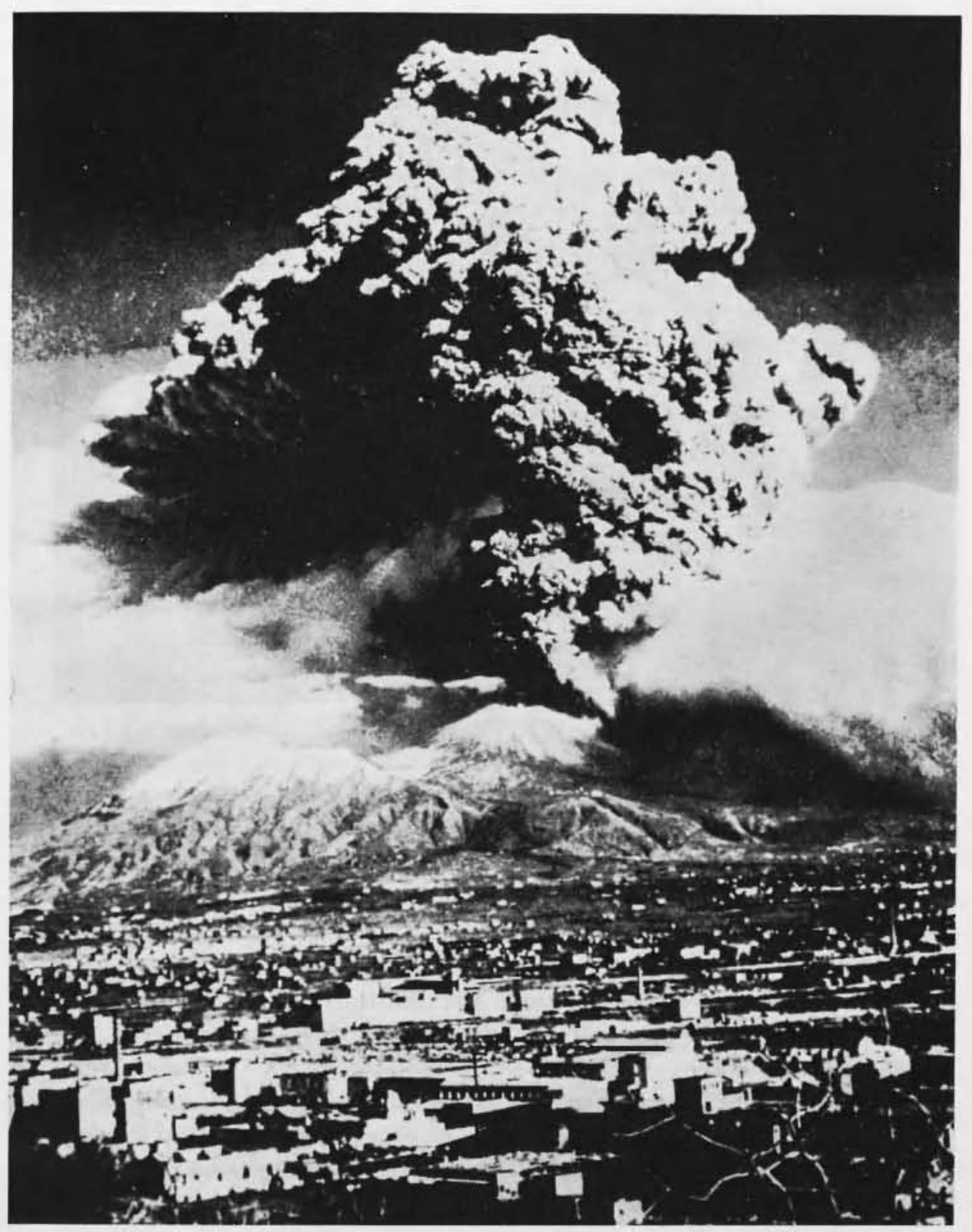

Photo 17 - A typical califlower-form cloud over the Vesuv (after Imbò). 
These subtypes can be experienced from time-to-time in the activity of Javanese volcano Merapi.

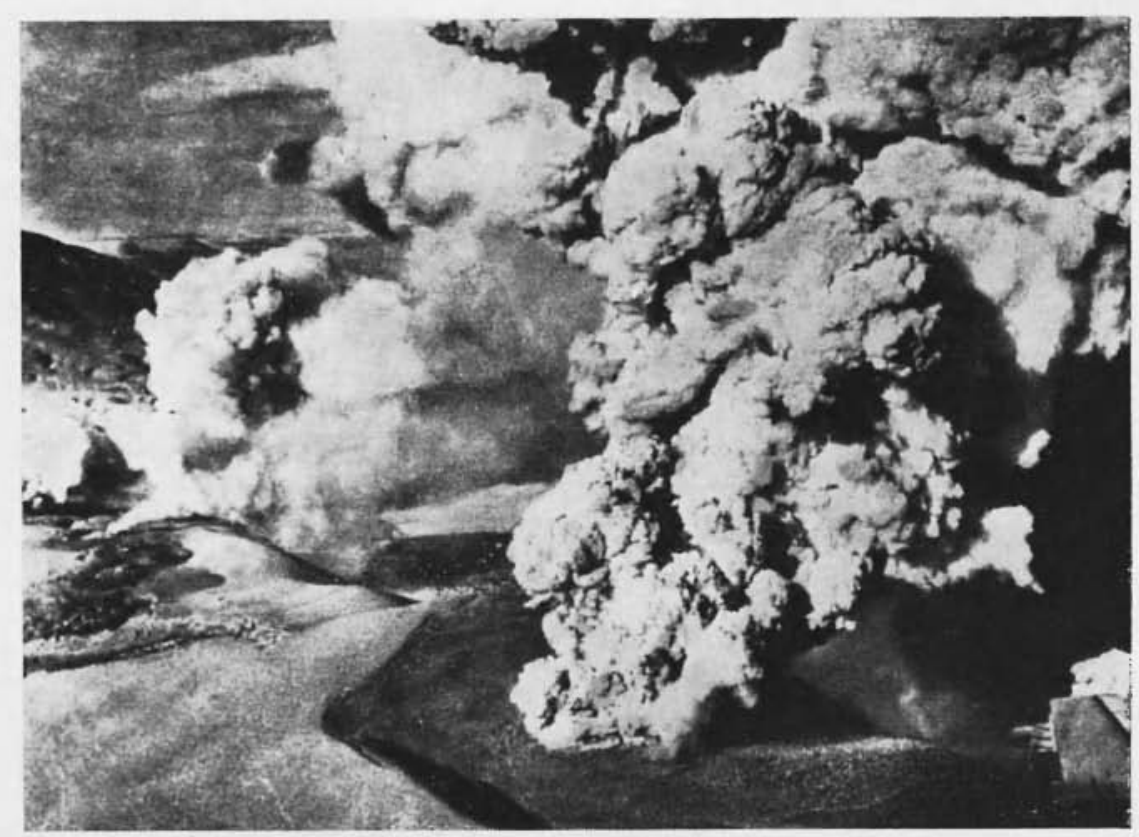

Pluto 18 - Eruption of Puyehne of Chile in 1960, immediately following the strongost shock of the great Clilean earthqualie-sequence.

15. Strombolian type. It is identical with the Strombolian Class (see Table IV). Continuous activity during hundreds and thousands of years. Phytmic gas-explosions. The gas-pressure however is not too strong. The volcano produces glowing fragments of lava, however the quantity of asles is very small and thus the eruption-cloud is white. The fragments of lava usually fall into the active erater itself. On the surface of the lava in the crater there is only a thin crust. The explosions break out this crust. $\mathcal{A}$ volcano, belonging to the Strombolian type sometimes may have a typically Hawaiian eharacter (for instance: Mihara-yama, 1950-51). On the other hand, a volcano which belongs to the Vulcanian type, may produce phenomena cliaracteristic of the Strombolian activity (for example: Etna, Vesuv). Further cxamples: Izalco (Salvador), Aso-san (Japan), Alaid (Kuriles), Uracas (Izu-Mariana group). 
16. Vulcanian type. It is identical with the Vulcanian C'lass (see Table IV). The name of this type originates from the name of Vulcano of the Iipari-islands, the activity of this voleano between 1888 and 1890 had been typically "Vulcanian". The Vesuv, however, often slows plienomena which are still more characteristic ones by the respective type than that of the Vulcano itself. The Vulcanian type probably is the most common one among the volcanoes of the Earth.

The lava is very viscous. It doesn't remain fluid a long time on the contrary - it solidifies quickly still in the crater.

Owing to the strong explosivity, the gases carry a great quantity of aslies and otlier small fragments into the air. Therefore the califlower-shaped eruption-cloud is very dark. The crust of the volcanic bombs is similar to that of the bresul. The form of the bombs is often angular. They originated partly from the lava, solidified insisle tle crater and partly from the older rocks of the crater-walls.

The first part of activity is somewhat similar to that of the Peléean type, but witlont nuées ardentes. The lava-flows are extremely rare, but lava-plugs are possible. The gas-explosions may destroy these plugs. If there are lava-flows, then it is a typical Vesuvian activity (Vesuv-I type which is not identical with the Plinian outburst, that is with Vesuv-II type, see later).

Some examples are as follows: Parícutin (Mexico), Asama-yama, Minami-dake, Sakura-zima (not in every cases but casually these tluree Japanese volcanoes show Vulcanian activity), Anak Krakatoa. (Indonesia, inside the Krakatoa-caldera), Palea and Nea Kameni (Greece, inside the Santorin-caldera), Irassen Peak (USA, not in the case of all of its outbursts), Kljuchewskaja, Mali Semjachik, Karymsky, Avachinsky, Clikurachky, Ksudach, Ilinsky, Ebeko, Sarichew, Kizimen, Zupanowsky, Koriatsky, Mutnovsky, Goreli Khrebet, Zeltlıowsky, Nemo Peak, Raikoke, Berg, Kudriavi, Atsonopnri (Kamchatka).

17. Tolachidake type (on the basis of its activity in 1926). Pyroclastic-fall and -flow of andesitic, usually acid andesitic materials. Explosive eruption of dacitic lava is possible. The explosivity is stronger than in the case of the proper Vulcanian type (point 16). It is a transition from the Vulcanian type towards the Merapi- and Peléean types. Examples: Saknra-zima in 1939 (t)is ontburst was followed by a small but typical nuée ardente), Komagatake (also of Japan) in 1939. The eruption of Komagatake in 1939 was followed from the emergence of an eruption-cloud with a lieight of $15 \mathrm{kms}$ (?). 
18. Suwanose-jima type. Basaltic and basic andesitic eruptions, in close relationship with the Strombolian type (point 15). The detonations are not totally rhytmic, since sometimes there are strong and very strong explosions too, inside a series of the detonations. The pause between two consecutive explosions is rather short, usually some seconds only. Many ashes and scoriae. Example: sometimes the Milara-yama; in such cases it has an efiusive and mixed character. During the last eruption in 1707, the Fuji Yama of Japan showed phenomena charucteristic to this type.

19. Prléean type. It is identical with the Peléean Class (see Table IV). It is the most explosive type among the other ones, discussed till the present point. Gigantic quantity of fragmentary-and ashesmaterial. In the crater a lava-plug originates, which may be lifted later by the gas-pressure and thus it forms a lava-spin or lava-tower. The explosions from beneath such a lava-tower have a more or less horizontal direction. There is no lava-flow, except the case when the lava-tower collapses or explodes. Nuées ardentes and direted volcanic blasts [the denomination of the latter phenomenon is due to Gorshkov (")] are frequent. These directed blasts, however, are weaker than that of Bezymianny (see in point 23). The directed voleanic blast in ease of Peléean type doesn't destroy the volcanic structure. Its energy - also according to Gorshkov $\left({ }^{7}\right), \ldots$ is $<10^{21}$ ergs which is the order of the total explosive energy of an atomic bomb of Bikini-type. The energy of directed volcanic blasts in the Bezymianny case is ten-, hundred, or even thousnnd-times bigger than in the case of Peléean type.

Subtypes:

a) Lassen Peak (without glowing avalanches);

b) Hibok-Hibok (with glowing avalanches).

Examples: Mont Pelée, 1902. V. 8, V. 20, VIII. 30; Sheveluch of Kamchatka in more occasions between 1946 and 1950; Lassen Peak of California, 1915. V. 19, and V. 22; Lamington of New Guinea, 1951; Hibok-Hibok of Philippines, 1951; La Soufricre of St. Vincent in 1902, preceling with only two days of the great eruption of Mount Pelée of Martinique.

According to Tazieff. (19), Nea Kameni, the active volcanic island at the center of the Santorin-caldera, often has a Peléean activity (and in other times it has the characteristics of Vulcanian eruptions, as it was mentioned earlier). 
20. Aso Nakadate type. It is in close relationslip with the Suwanose-jima type, discusserl in point 18. Its activity, however, is never eflusive or mixed but always fragmentary. The material of its teplura is basaltic or basic: andesitic.

21. Vesue-I type. It represents a form of voleanie activity, wlich directly precedes the Plinian type (see in point 25) and especially the paroxysm of the Plinian eruption. At the same time it is the more violent version of the Strombolian- and Vuleanian Classes. It is sometimes preceded by phreatic activity. The gigantic eruption-cloud lats a califlower-shape, which is extremely clark and in which fantastic electrical phenomena may oceur (example: the eruption of VesuvMarch, 1944).

The rlifference between the Vulcanian type and Vesuv-I type is that in the latter case the lava-flows are possible (3).

22. Phreatie and phreatomamatic types. See Table VI.

23. Bezymianny type (on the basis of the activity of this voleano of Kamchatka in 1955-56). After many thousands preliminary earthquakes a gigantic clirected blast occurred and iestroyed a great part of the voleanic structure. Pyroclastic-flow with a lengtl of $18 \mathrm{kms}$. Very strong air-wave(s). New calclera of explosive origin. Insifle the caldera a new dome formeil from very viscous lava and increased gradually as the time elapsed. However some relationship is without Iloubt with the eruption of Katmai in 1912 - according to Tazieff (20)

- their character evidently was not quite the same, against the Gorshkov's opinion ( ${ }^{5}$ ). In the case of Bezymianny - namely - there was no iqnimbrite at all and the eruption was a eentral one; while in the Katmai eruption an ignimbritic outbursts occurred from linear fissures.

According to Gorshkov (8) the eruption of Seveluch - Kamchatka (November 12tli, 1964) also belonged to the Bezymianny type.

24. Ytrian type. In accordance with the statements, discussed previously in this paper, the eruption of Ytri had been - for a certain degree - a pseudovolcanic phenomenon, since its high gas-content was the consequence of a subglacial eruption $\left.{ }^{2}\right)$.

25. Vesuv-II. (Plinian) type. One of the main characteristics of such kind of eruptions is the transformation of the form of the top 
of voleanie mount, partly and in a smaller measure by very strong explosions and partly, on a larger scale as a consequence of gravity slicles, producing the wall(s) of the somma (see the Introduction). Many millions tons of ashes, lapillis and bombs. Extremely dark the eruption-clond which becomes later similar to the shape of a gigantic pine-tree. Inside the crater there lad been a lava-plug, but during the Plinian phase this plug is slestroying partly or totally by the force of detonations. After tlis event there may be lava-1lows, sometimes on a great scale. According to ('otton (4) the most violent voleanic outbursts of the human history belonged to this type. Plinian eruptions occur usually after a long dormaney of a voleano. The period of quiesence may be hundreds or thousands of years. According to Cotton the "Pompeian" eruption of Vesuv (79, A.D.) might have been partly a phreatic (ultravulcanian) one.

Perret-phase (gas-phase): the paroxysm of the Plinian type. More (ietails are in Van Bemmelen's paper (2).

Examples for the Plinian type: Vesuv 79, $\Lambda$. I)., and Merapi, 1006, A. D.

26. Santorin type (on the basis of its prehistoric so called "Minoan" activity, between 1500 and 1400,13 . C.). It is in a rery close relationship with the Plinian type. The only diflerence between the Plinian type and the Santorin type is that in the Santorin case a great deal of the volcanic structure "disappeared" from the surface of the Earth wlile in the case of the "Pompeian" eruption of Vesuv only the material of the top of the volcanic mount liad been transformed by slide(s).

Disregarding from this difference, the "Hinoan" eruption of Santorin had been a typically Plinian one $(2,16,22$ etc.). The collapse of the volcanic structure was the direct consequence of the collajse of the upper part (roof) of the magma-chamber. However about one per cent of the volcanic mount had been destroyed by effective explosions (Fouque). Glowing avalanches, nuees ardentes, extremely strong air- and seawaves (tsunamis) as well as tornadoes and leavy rains were also possible, probably together with lahars. Gigantic quantity of tephra, including pumice. It is possible that the "Minoan" eruption began as a phreatic (or phreatomagmatic) one.

Examples: Mount Mazama (Crater Lake, Oregon) about 6000, B. C.: Tambora (Indonesia) 1815: Krakatoa (Indonesia) 1883. Tsunamis occurred in case of Tambora and Krakatoa outbursts. 
27. Katmaian type. The only example for true ignimbritic eruptions in the historical times. According to van Bemmelen ('), it differs from the Plinian type in the meaning that its energy as well as the volume of its tephra was still greater than that of the Plinian outburst of Vesuv in 79, A. D. On the other hand the eruption of Katmai of Alaska was not central but linear. Directed volcanic blasts, nuées ardentes has taken place. Extremely dark eruption-eloud. The lava had been foamed at the edge of the open fissures. The tephra didn't fly high into the air from the fissures. Origin of ignimbrite. The activity might have started as a phreatic eruption.

28. Type of prehistoric ignimbritic eruptions. In the geological past time the ignimbritic eruptions had been more frequent than at present time and they had been still stronger than the Katmai outburst in 1912 .

Example: New Zealand.

As it was partly mentioned earlier, too, the phreatic and/or phreatomagmatic eruptions have or at least may have a role in the activity of types $16,19,21,23,25,26$, and 27 .

\section{ACKNOWLEDGEMENT.}

The author is very indebted and grateful to Dr. Neumann van Padang and Professor R. W. van Bemmelen for their valuable criticism on this paper.

\section{REFERENCES}

(1) Bemmelen R. W., vaN, Folcanology and Geology of Ignimbrites in Indonesia, North Italy, and the U.S.A. "Bulletin volcanologique", XXV, 1963. 
(-) Bryseryx R. W., van, Four Voleanic Outbursts that Infuenced Iuman IIistory - Toba, Sunda, Merapi and Thera. Idecture on International Scientific Congress on the Volcano of Thera (ISCV'T), Athens, 1969. (All pajers of lectures on ISCV' will he prublished in the Acta of the (Congress).

(') Butand F. M., Voloanoes in Nistory, in Theory, in Eruption. Austin, 1968.

(1) Cotron (.. A., Voleanoes as Landscape Forms. New York, 1969.

(5) Gonsisov (4. S., Gigantic Eruption of the Voleano Bezymianny. "Bulletin volcanologique ", Série II, XX, 1950.

(') Consukov (1. S., On the Classification and T'erminology of I'elée amd Kutmai Type Eruptions. "Bulletin volcanologique", XXIV, 1962.

(") Gonsıkov ('. S., Direcled Volcanie Blasts. "Bulletin volcanoiogique", XXVI, 1963.

(8) Goustrkov G. S., Gigantic Directed Hlast at Sheveluch Volcano, Hamehatha). "Bulletin voleanologicue", XXXIV, I, 1070.

(") IlÉnenvárı P., A New Classification of the Voleanic Eruptions, "Gerlands Beitrigge zur Geoplyysik", 71, 2, 1962.

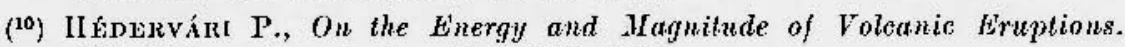
"Bulletin voleanologique", XXV, 1963.

(12) II ÉDEnVÁn P., Voleanopluysies; Energetics of Eruption and: Volcanophysics; Magnitude of Eruptions. Encychopedia of Geophysics, Structure and Petrology (edl.: Fairibidge R. W.), in press, 1970.

(12) 1 мьо̀ G., Eruptive Energies. "Annali dell'Osservatorio Vesuviano", Sorie VI, VII, 1965.

(19) Мімккамт T., Fundamental Research for Predinting Volcanic Eruptions. Part. I. "Bulletin of Eartliquake Research Instituto", 38, 4, 1960.

(29) Neumann van Padang N. M., Discussion on the Paper "A Suggestion for the Application of New Symbols in the Short Description of Different Volcanic Phenomena" by P. HÉdervárr. "Bulletin volcanologique", XXXIII, 2, 1969a.

(15) Neumann van Patang N. M., Two Calastrophic Eruptions in Indonesia, Comparable with the Plinian Outburst of the Folcano of Thera (Santorini) in Minoan Time. ISCVT, 1969b.

(16) Riciter C. F., Elementary Seismology. San Francisco, 1958.

(17) Rittsaxin A., Foleanoes and their Aativily. New York, 1962.

(18) Stmmozuru D., Berg E., Seismological Study of the Nyiragongo Volcano. "Bull, des Siciences, Ac. Royale des Sei. d'Outre-Mer", VII, 4, 1961.

(18) TaziefF H., Volcanoes. Paris, 1961.

$\left.{ }^{20}\right)$ TaziefF H. et al., Contribution à l'étude Volcanologique du Katmai et de la Vallée des Dis Mille Fumées (Alaska), "Hómoires de la Sociétó Belge de Géologie", Sórie in 8, No. 7, 1963.

(21) Tsuya H., Monimoto R., Types of Tolcanie Eruptions in Japan. "Bullettin volcanologique", XXVI, 1963. 
(22) Vitaliaxo Cu. J., Vitaliano D. B., Plinian Eruptions, Earthquakes, and Santorin. "A Review", ISCVT, 1969.

(23) Vlodavetz V. I. et al., Relations Belireen the Type of Eruptions and the Composition of lawa as Lxemplified by Kamehatka and Kuriles Tolcanoes. "Bulletin voleanologique", XXVI. 1963.

(24) Yagi K., Some Genetic Problems of the Calderas in Japan. ISCVT, 1969. 